\title{
Recent insights on indirect mechanisms in developmental toxicity of nanomaterials
}

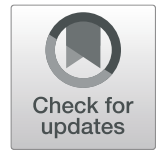

\author{
Battuja Batbajar Dugershaw', Leonie Aengenheister ${ }^{1}$, Signe Schmidt Kjølner Hansen², \\ Karin Sørig Hougaard ${ }^{2,4}$ and Tina Buerki-Thurnherr ${ }^{1 *}$ (i)
}

\begin{abstract}
Background: Epidemiological and animal studies provide compelling indications that environmental and engineered nanomaterials (NMs) pose a risk for pregnancy, fetal development and offspring health later in life. Understanding the origin and mechanisms underlying NM-induced developmental toxicity will be a cornerstone in the protection of sensitive populations and the design of safe and sustainable nanotechnology applications.

Main body: Direct toxicity originating from NMs crossing the placental barrier is frequently assumed to be the key pathway in developmental toxicity. However, placental transfer of particles is often highly limited, and evidence is growing that NMs can also indirectly interfere with fetal development. Here, we outline current knowledge on potential indirect mechanisms in developmental toxicity of NMs.

Short conclusion: Until now, research on developmental toxicity has mainly focused on the biodistribution and placental translocation of NMs to the fetus to delineate underlying processes. Systematic research addressing NM impact on maternal and placental tissues as potential contributors to mechanistic pathways in developmental toxicity is only slowly gathering momentum. So far, maternal and placental oxidative stress and inflammation, activation of placental toll-like receptors (TLRs), impairment of placental growth and secretion of placental hormones, and vascular factors have been suggested to mediate indirect developmental toxicity of NMs. Therefore, NM effects on maternal and placental tissue function ought to be comprehensively evaluated in addition to placental transfer in the design of future studies of developmental toxicity and risk assessment of NM exposure during pregnancy.
\end{abstract}

Keywords: Nanomaterials, Developmental toxicity, Indirect toxicity pathways, Placental barrier, Pregnancy

\section{Background}

Since the thalidomide scandal in the early 1960s, it has become evident that the placenta does not provide a tight barrier, and that fetuses are exceptionally susceptible to potentially toxic substances compared to adults, due to the phases of rapid growth, range of developmental events and often irreversible nature of the induced changes [1]. The first indications of developmental

\footnotetext{
* Correspondence: tina.buerki@empa.ch

'Laboratory for Particles-Biology Interactions, Empa, Swiss Federal

Laboratories for Materials Science and Technology, Empa, Lerchenfeldstrasse 5, 9014 St.Gallen, Switzerland

Full list of author information is available at the end of the article
}

toxicity of nanosized particles came from epidemiological studies, showing association of particulate matter (PM) exposure with adverse pregnancy outcomes such as low birth weight, preterm birth and preeclampsia [2-4]. Recently, it has been confirmed that environmental black carbon reaches the fetal side of the placenta in exposed pregnant women [5]. With the advent of nanotechnology, novel NMs with unique properties can be industrially produced at large scales for application in food (reviewed in $[6,7]$ ), cosmetics (reviewed in $[7,8]$ ), medicine (reviewed in $[9,10])$ and high-technology products (reviewed in $[10$, 11]). These engineered NMs further contribute to human exposure to nanosized particles, and due to their high 
reactivity, pose additional health risks. However, investigations of the toxicological effects of engineered NMs, especially in vulnerable populations such as pregnant women and their unborn children, have lagged behind the development of new applications. Importantly, to support safeby-design and sustainable use of NMs, it is imperative to gain knowledge on the potential developmental toxicity of NMs and to understand the mechanisms underlying such toxicity.

In principle, NMs can affect fetal development through two fundamentally different pathways: a direct and an indirect pathway [12] (Fig. 1), that, however, are not mutually exclusive. Direct developmental toxicity may arise from particles in maternal blood that cross the placental barrier [13-15] and directly damage fetal tissues due to their high surface reactivity and propensity to induce inflammation [16-18], reactive oxygen species (ROS) [19] and hence oxidative stress reactions [20-22], among others. Several FNMs are able to cross primary biological tissue barriers (e.g., lung [23, 24] and gastrointestinal (GI) tract [24, 25]) as well as the placenta [26-29], even if translocation is usually rather limited [30, 31]. Direct effects on embryonic and fetal tissues have been described for a variety of NMs in several in vitro studies as well as across species, including fish, chicken, and in vitro human stem cell (SC) models (reviewed in [32]). However, findings from organisms that lack a placenta or have a distinctly different placental structure might not directly correlate to the human condition.

The potential for NMs to affect fetal development by indirect pathways has been only marginally investigated and understood. Here, the concept is that NMs can interfere with fetal development in an indirect manner without being in direct contact with fetal tissue (Fig. 1). NMs deposited in primary maternal tissue barriers at the point of entry following oral, inhalation, dermal or intravenous (i.v.) exposure might induce oxidative stress and subsequently inflammation, leading to the release of inflammatory mediators and soluble signaling factors that can reach the placenta and fetus to induce potential toxic effects (maternal mediated developmental toxicity). Alternatively, particles reaching the placenta can cause similar responses in the placental tissue, compromising

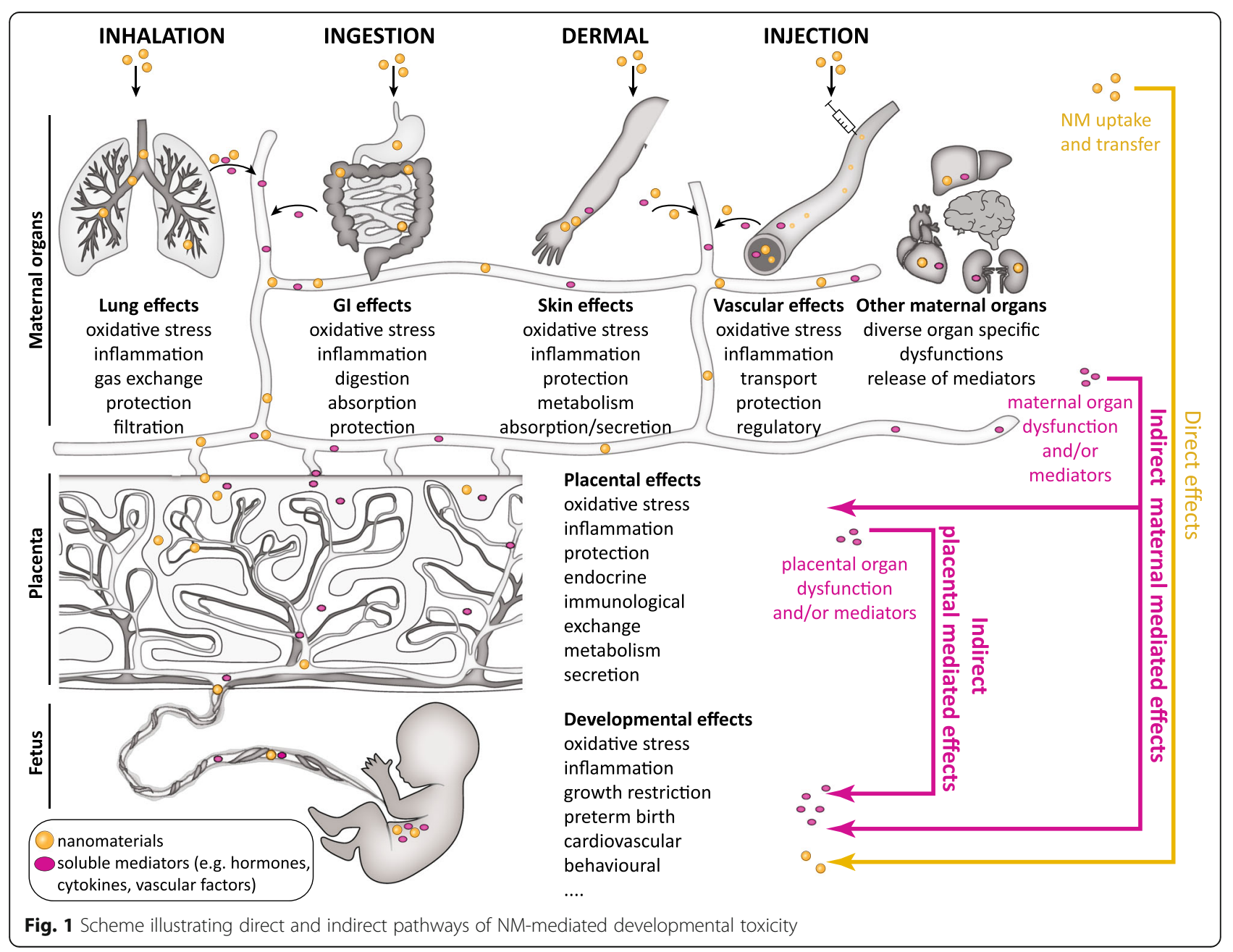


placental function and inducing the release of placental signaling factors, which might impair embryo-fetal development (placental mediated developmental toxicity).

The aim of this review is to (i) collect the current knowledge base on the indirect developmental toxicity of NMs, (ii) compile and describe already known signaling pathways, (iii) propose novel candidate pathways and (iv) suggest directions of future research needs.

\section{Risks and opportunities of NMs in pregnancy}

For a proper risk assessment of NMs, a central aspect is to understand the exposure of pregnant women to NMs, including all relevant routes of exposure [33]. Due to the use of NMs in many consumer, high-technology and biomedical products, pregnant women could be exposed to NMs via inhalation, absorption through damaged skin, ingestion or injection (Fig. 1) (reviewed in [34, 35]). At production sites with applications of NMs, pregnant women can be exposed to NMs by inhalation, since the established protective legislation [36] does not come into action until the employer is made aware of the pregnancy, most often not until after the first 4-6 weeks. Even then, NM exposure might continue, as the regulation does not specifically regulate NM relative to pregnancy $[37,38]$. Ingestion of NMs used as food additives, in food packaging material or personal care products, constitutes another realistic route of exposure during pregnancy. For example, the white food colorant E171 consists of particulate titanium dioxide $\left(\mathrm{TiO}_{2}\right)$, with approximately $17-35 \%$ of the particles being within the nano-range (reviewed in $[7,39,40]$ ), and is present in toothpaste and various food products such as beverages, soups, cakes or candy in the European Union [41, 42]. In the United States, the dietary intake of $\mathrm{TiO}_{2}$ is estimated to be $1-2 \mathrm{mg} / \mathrm{kg}$ body weight per day for children, and $0.2-0.7 \mathrm{mg} / \mathrm{kg}$ body weight per day for other age groups $[7,42]$. Dermal uptake of NMs present in personal care products, such as sunscreen, is expected to be minimal since the intact skin forms a tight barrier for NMs (reviewed in [43]). Finally, particles may be directly injected into the body in case of medical application of NMs (reviewed in $[9,44,45]$ ), but currently, nanomedical therapies during pregnancy are still in the investigational stage. For instance, King et al. demonstrated the potential of iRGD (9-amino acid cyclic peptide: CRGDKGPDC)-decorated liposomes loaded with insulin-like growth factor (IGF)-2 for the treatment of fetal growth restriction in mice [46]. An oxytocin receptor coated liposomal carrier loaded with the tocolytic drug indomethacin substantially decreased preterm birth rates in mice [47]. Nevertheless, before clinical use in pregnant women, not only the efficacy of the potential treatment in humans but also the safety of the NMs during pregnancy needs to be proven.
I.v. injection would make NMs readily systemically available. In contrast, only a low fraction of air and foodborne NMs would be expected to reach the systemic circulation and become bioavailable for maternal, placental and fetal tissues. Dermal exposure is expected to contribute very little to the systemic burden [27, 31]. Once NMs have reached the systemic circulation, they can distribute to maternal organs, including the placenta. As a highly perfused organ, the placenta is extensively exposed to circulating substances. Placental cells have been described to take up nanosized particles from the blood stream in experimental animals as well as the ex vivo human placenta perfusion model (e.g. [48-51]). Studies on placental translocation of NMs in rodents, in the human ex vivo and in in vitro placenta models have shown that some types of NMs are retained in the maternal circulation while others can pass the placenta (reviewed in $[26,52])$. Placental transfer appears to partially correlate withphysicochemical properties of NMs, in particular particle size [26]. However, other factors such as the gestational stage or combined physico-chemical properties can also affect placental translocation of NMs, making this process difficult to predict [53]. As an example, a recent study demonstrated decreased fetal viability and growth, when $13 \mathrm{~nm}$ zinc oxide $(\mathrm{ZnO}) \mathrm{NPs}$ were orally administered ( $7.2 \mathrm{mg} /$ mouse) during organogenesis (gestational day (GD)7-16) in mice. However, when $\mathrm{ZnO}$ NP exposure occurred during the peri-implantation period (GD1-GD10) no fetal toxicity, but a slight change in placental weight, was observed [54].

For most routes of uptake (inhalation, ingestion and injection), gestational NM exposure has been associated with developmental toxicity for a variety of different NMs (extensively reviewed in $[36,55-58]$ ). However, we have yet to identify the underlying mechanisms and which particle properties are of particular concern.

\section{Organ systems of relevance for pathways of indirect developmental toxicity}

For sure, the placenta should be a key focus in any mechanistic study on NM-mediated developmental toxicity due to its position at the interface between mother and fetus and its numerous essential functions during pregnancy. As a transient organ, the placenta starts forming after implantation of the conceptus in the uterine wall. It consists of tissues of maternal (decidua) and fetal origin (amnion, chorion) [59, 60]. Anatomically, the maternal side of the placenta comprises the multinuclear syncytiotrophoblast (ST) layer, which is supported by a basal membrane, underlying cytotrophoblast cells, mesenchymal tissue and the microvascular endothelium of the fetal small blood vessels (Fig. 2). This interface between the inner mucous membrane of the uterus (endometrium) and the fetus defines the degree to which 

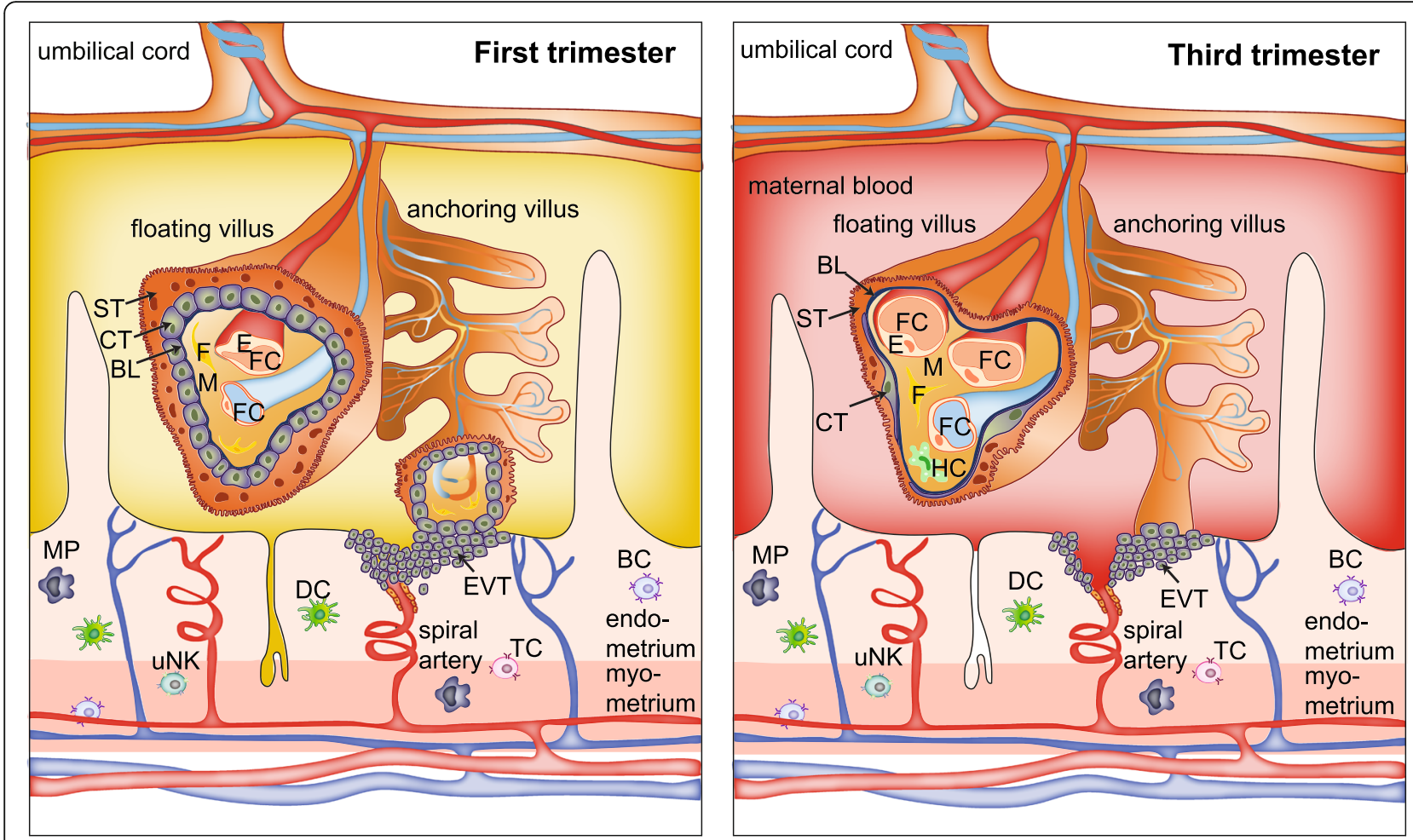

Fig. 2 Scheme of the human placental barrier in early and late pregnancy. In the first trimester, the placental barrier consists of the syncytiotrophoblast (ST), cytotrophoblasts (CT), basal lamina (BL) and the endothelial cells (E) of the fetal capillaries (FC). Other cell types in the villous mesoderm include fibroblasts (F) and Hofbauer cells $(\mathrm{HC})$. Various immune cells are also present in the maternal decidual tissue, including dendritic cells (DC), macrophages (MP), uterine natural killer cells (UNK), T cells (TC) and B cells (BC). Extravillous trophoblasts (EVT) of the anchoring villi invade the maternal spiral arteries (SA) and form a plug that prevents entry of maternal blood into the intervillous space, and uterine glands (UG) provide histiotrophic nutrition. After the first trimester, the EVT plug is released and placental villi are now surrounded by maternal blood. Towards the end of pregnancy, the placental barrier decreases in size by thinning of the ST layer and spreading of the CT layer, and the FCs move towards the periphery of the floating villi

maternally delivered substances reach the fetal tissue [61]. During pregnancy, the placenta undergoes dramatic structural and functional changes to fulfill the evolving needs of the developing fetus. During early pregnancy, the placental barrier is relatively thick $(20-30 \mu \mathrm{m})$ and bilayered [62-64], but thins $(2-4 \mu \mathrm{m})$ [65], becomes predominantly monolayered [62-64], and increases its surface area tremendously (to approx. $12 \mathrm{~m}^{2}$ ) towards the end of pregnancy to allow for efficient exchange of nutrients and gases required to sustain rapid fetal growth. Placental damage, disease or impairment of its development or function are responsible for numerous pregnancy complications, including preeclampsia [66], miscarriage $[63,67]$ and intrauterine growth restriction [63, 67], and can likely impact offspring health later in life [68]. It should also be highlighted that the placenta is the most species-specific organ among mammals and shows remarkable differences in global structure, tissue layer organization, trophoblast cell types $[69,70]$ as well as molecular features [71]. Therefore, translation from animal studies to the human situation should be done with caution, and the use of physiologically relevant placenta models is encouraged.

Also, maternal organs could mediate indirect developmental toxicity of NMs. Here, a focus should be on tissues at the port of entry that are in direct contact with particles such as the lung, the skin or the GI tract upon inhalation, dermal deposition or oral exposure, respectively. Uptake and accumulation of NMs in these tissues could affect organ functions locally, but effects may spread to distant sites, including the placenta or the developing fetus, if particles interfere with essential signaling pathways. This concept is nicely exemplified in a recent study in mice, where systemic adverse effects (i.e. increased retention of activated leukocytes, secondary thrombocytosis, and pro-inflammatory responses in secondary organs) were observed only upon inhalation exposure to carbon NPs, but not after intra-arterial injection of an equivalent dose of particles to bypass the lung [72]. The mechanism(s) underlying the observed indirect systemic toxicity of carbon NPs appeared to involve inflammatory responses of the lung tissue [72]. In addition to pro-inflammatory actions, NMs may also 
interfere with essential functions of the lung, skin or GI, such as gas exchange, digestion, nutrient uptake, metabolism or transport (Fig. 1). For instance, ZnO NPs can reduce iron and nutrient uptake and transfer at the intestinal barrier [73, 74].

\section{Evidence for indirect developmental toxicity}

To gather an overview on potential indirect pathways in developmental toxicity, we searched the open literature for studies reporting adverse effects of NMs on gestation and fetal development in the absence of detectable materno-fetal particle transfer (Table 1). However, since direct and indirect toxicity pathways may jointly contribute to developmental toxicity, we also included studies that provide hints for indirect toxicity pathways even if placental transfer of NMs was detected (Table 2) or unknown (Table 3). The studies are briefly described below alongside the provided evidence and forwarded hypotheses for indirect mechanisms of toxicity.

\section{Studies without detectable placental particle transfer}

We identified a total of ten studies that reported developmental toxicity in the absence of detectable NM translocation across the placental barrier (Table 1). Most used pregnant mice as the experimental model, but a few studies used in vitro cell culture systems for more mechanistic studies. Gestational and litter parameters were affected in four of the murine studies, including reduced survival rate of offspring from dams inhaling copper oxide $(\mathrm{CuO}) \quad\left(3.5 \mathrm{mg} / \mathrm{m}^{3}\right.$ at $\mathrm{GD}$ 3-19) [78], decreased fetal size and delayed neonatal growth from cadmium oxide $(\mathrm{CdO}) \mathrm{NP}$ inhalation $\left(100 \mu \mathrm{g} / \mathrm{m}^{3}\right.$ or $230 \mu \mathrm{g} / \mathrm{m}^{3}$ at GD 4.5-16.5) [83], and increased fetal resorption and malformations following maternal exposure to SWCNTs by the oral $(10$ or $100 \mathrm{mg} / \mathrm{kg}$ body weight at GD 9) [84] and i.v. route (10 ng to $30 \mu \mathrm{g} /$ mouse at GD 5.5) [85]. Other studies described effects on placental structure and function, offspring lung development and function and neurodevelopment. Regarding the placenta, intratracheal instillation of $\mathrm{TiO}_{2}$ and cerium dioxide $\left(\mathrm{CeO}_{2}\right)$ NPs (total $300 \mu \mathrm{g} /$ mouse: $100 \mu \mathrm{g}$ on GD 2.5, 9.5 and 16.5, respectively) decreased placental efficiency [76], injection of CdO NPs altered placental weight [83] and injection of SWCNTs induced vascular lesions and increased placental level of ROS [85]. Gestational NM exposure can also affect maternal and fetal lungs as exemplified by maternal lung inflammation induced by inhalation of $\mathrm{TiO}_{2}\left(42 \mathrm{mg} / \mathrm{m}^{3}\right.$ on GD 8-18) [77] or $\mathrm{CuO}$ NPs $\left(3.5 \mathrm{mg} / \mathrm{m}^{3}\right.$ on GD 3-19) [78], or long-lasting impairment of lung development in the offspring resulting from maternal intratracheal instillation of $\mathrm{TiO}_{2}$ or $\mathrm{CeO}_{2}$ NP [76]. Neurodevelopmental abnormalities, like reactive astrogliosis and increased DNA damage in the fetal hippocampus, have been observed after injection of cobalt-chrome (CoCr) NPs into pregnant mice on GD 9 (0.12 $\mathrm{mg}$ per mouse) [88]. In a similar direction, both maternal inhalation with $42 \mathrm{mg} / \mathrm{m}^{3}$ (GD 8-18) [77] and injection with $1000 \mu \mathrm{g} /$ mouse (GD 9) [75] of $\mathrm{TiO}_{2} \mathrm{NPs}$ caused behavioral deficits in the offspring.. Finally, immunomodulatory effects were reported upon $\mathrm{CuO}$ inhalation [78]. Importantly, NM translocation to the fetus was addressed but not observed in these studies, therefore strongly supporting the presence of indirect toxicity pathways. However, it is conceivable that a small amount of particles might have crossed the placental barrier, which were below the detection limit of the applied analytical techniques (i.e. ICP-MS, gAAS, TEM, histological and micro-Raman analysis), as for example suggested by Hougaard et al., 2010 [77]. Moreover, for soluble NPs (e.g. CuO), placental translocation of small quantities of dissolved ions might also partially account for developmental toxicity even in the absence of particle transfer. Nevertheless, the adverse effects upon $\mathrm{CuO}$ inhalation in mice observed by Adamcakova-Dodd et al. [78] were not associated with detectable increase in fetal or maternal blood $\mathrm{Cu}$ levels. Proposed pathways for indirect developmental toxicity included both placentaand maternally mediated secondary mechanisms. Maternally mediated pathways comprised oxidative stress, inflammatory, immune and endocrine responses [75, 77, $78,83,84]$, whereas placental mediated pathways involved oxidative stress, inflammation, placental insufficiency, release of mediators (e.g., ATP, IL-6) and changes in placental transport of zinc, vitamin B12, micronutrients or oxygen $[76,79-88]$

\section{Studies with placental particle transfer}

Several publications suggested a role for indirect developmental toxicity of NMs even if particles in some cases were shown to cross the placental barrier and adverse effects could have resulted from direct embryo-fetal exposure (Table 2). The gestational and litter parameters described in these studies include increased rate of miscarriage from quantum dot (QD) injection [89], smaller fetuses and increased fetal resorption from silica dioxide $\left(\mathrm{SiO}_{2}\right)$ and $\mathrm{TiO}_{2} \mathrm{NP}$ injection [90], growth retardation from diesel exhaust particle (DEP) inhalation [93] or multi-walled carbon nanotube (MWCNT) injection [94] and fetal organ damage from QD [89] or SWCNT/ MWCNT injection [94, 95]. The maternal parameters reported were decreased maternal body weight upon $\mathrm{SiO}_{2}$ and $\mathrm{TiO}_{2} \mathrm{NP}$ injection $(0.8 \mathrm{mg} /$ mouse on GD 16 and 17) [90] and hepatocellular injury from QD injection (100 mg/kg body weight on GD 17 in mice and $25 \mathrm{mg} /$ $\mathrm{kg}$ on GD 100 in monkeys) [89]. Paul et al. observed long-lasting impairment of lung development in offspring of pregnant mice intratracheally instilled with silver $(\mathrm{Ag}) \mathrm{NPs}$ (total $300 \mu \mathrm{g} /$ mouse: $100 \mu \mathrm{g}$ on GD 2.5, 9.5 


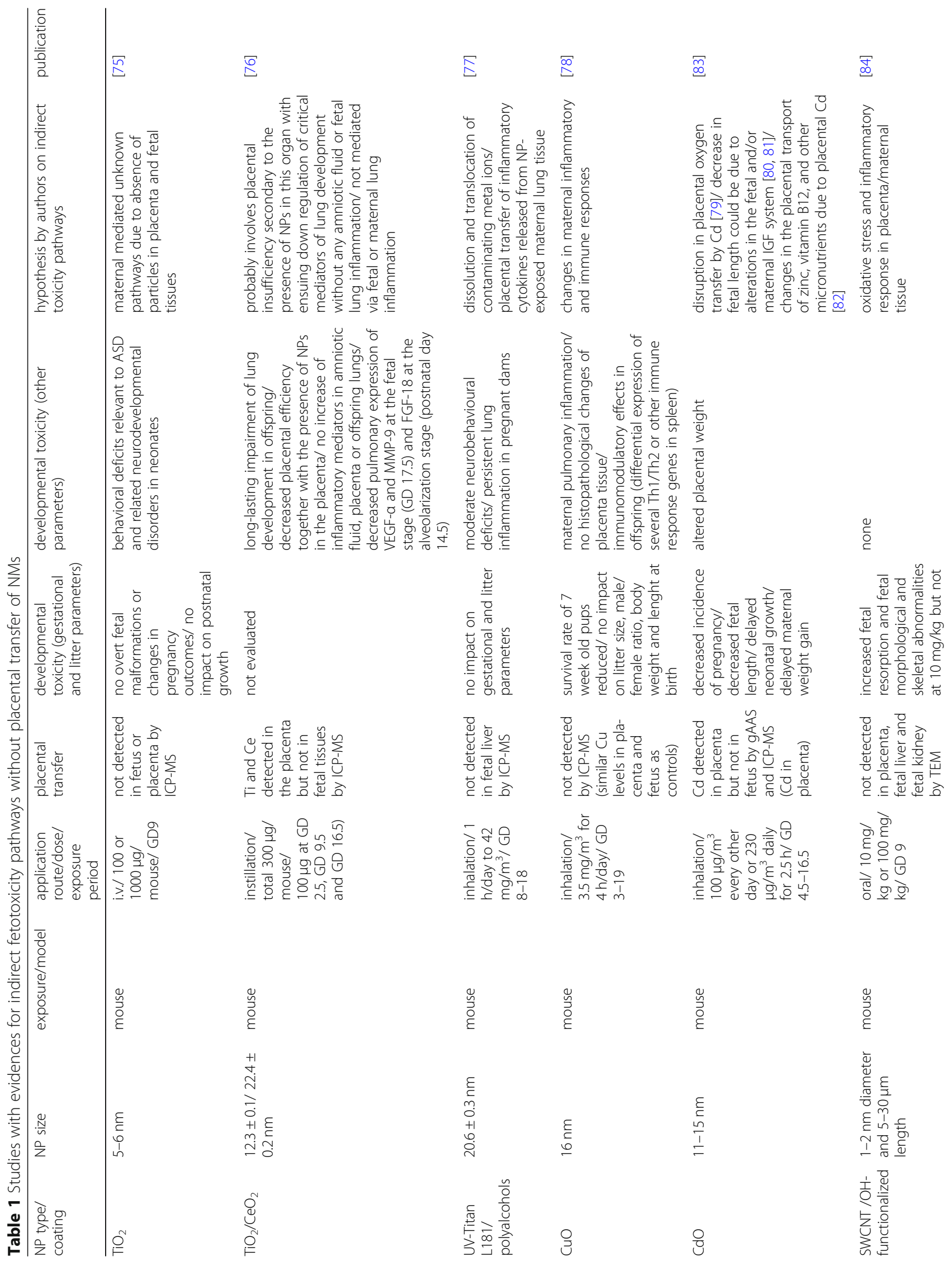




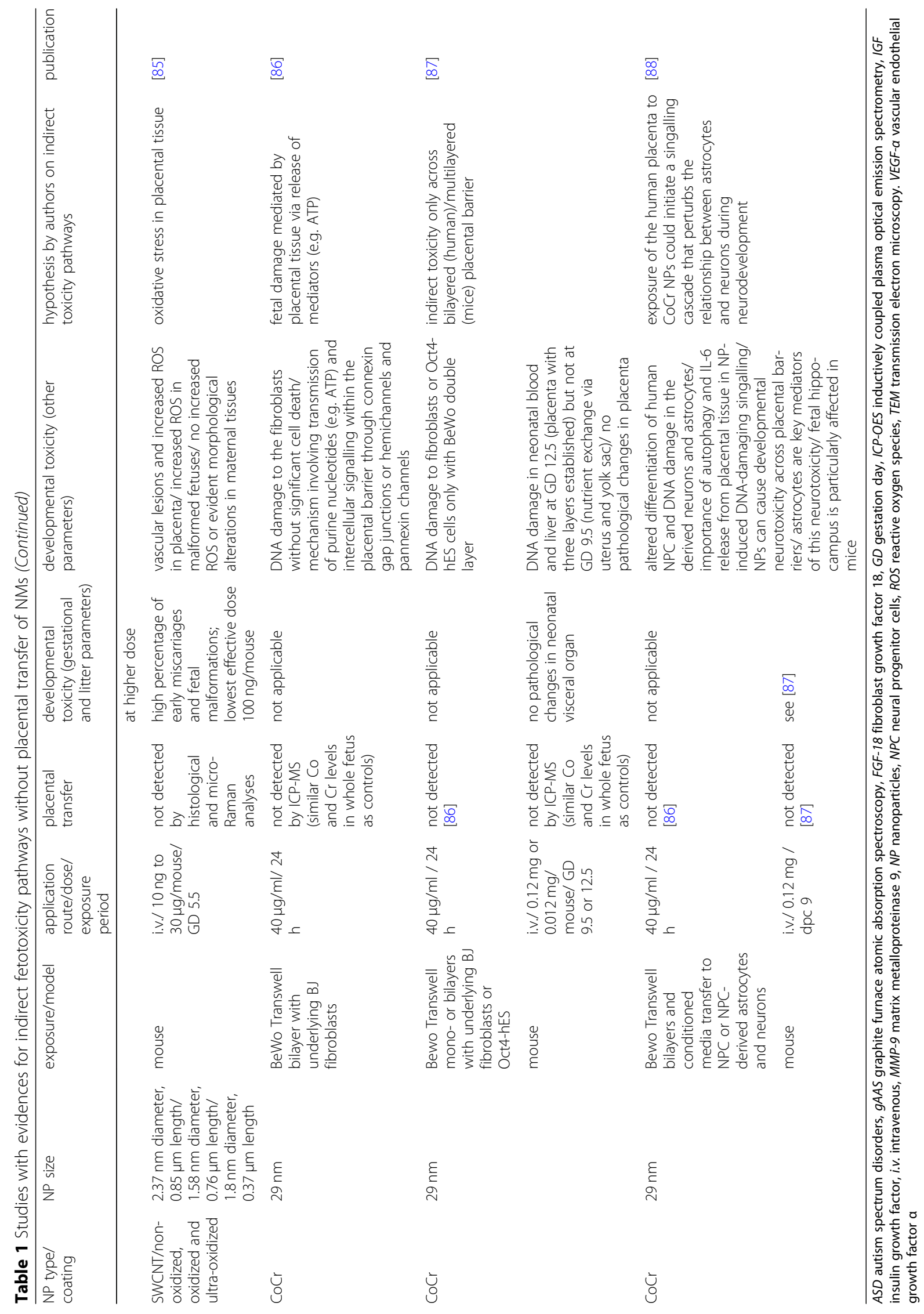




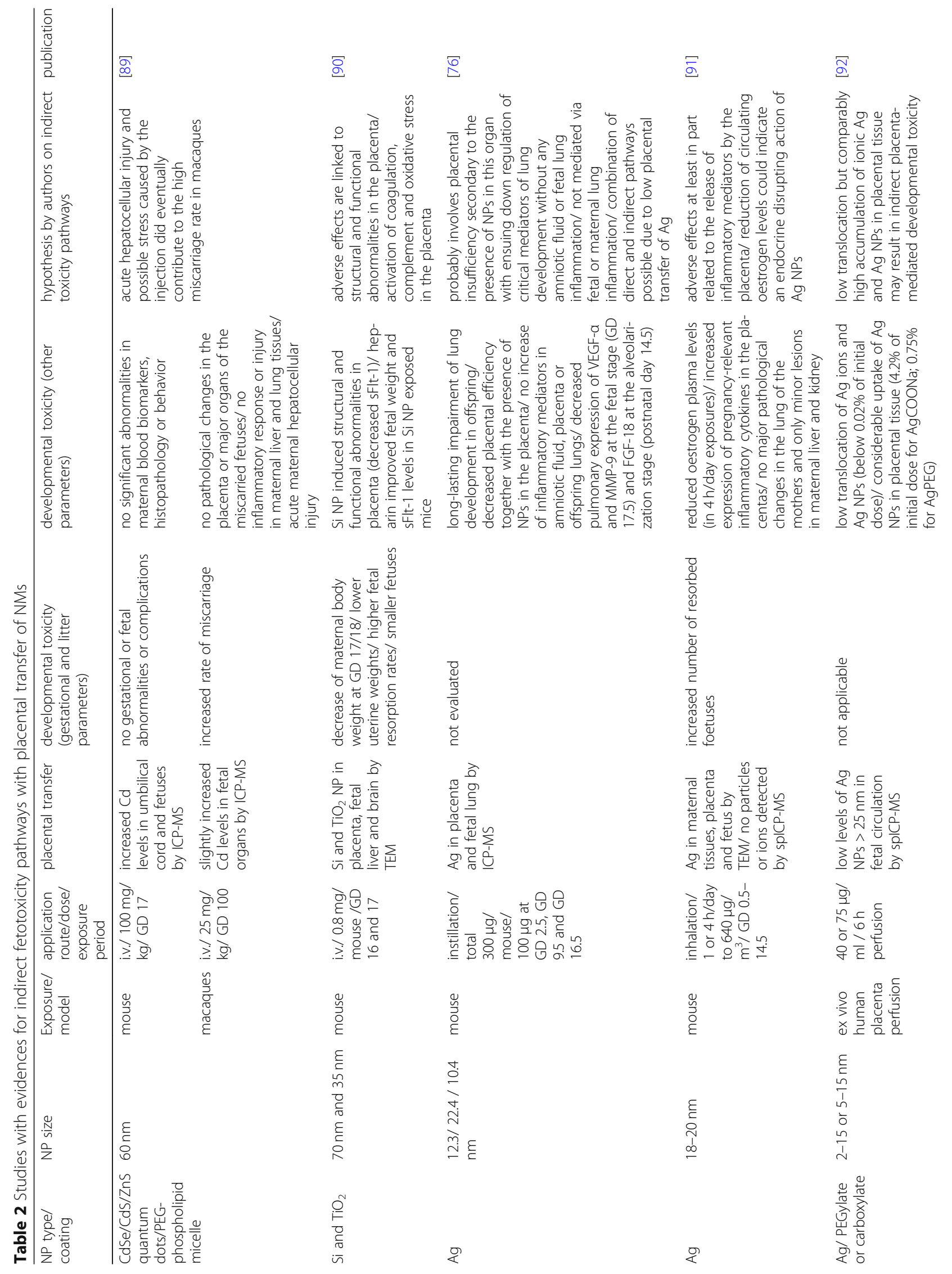




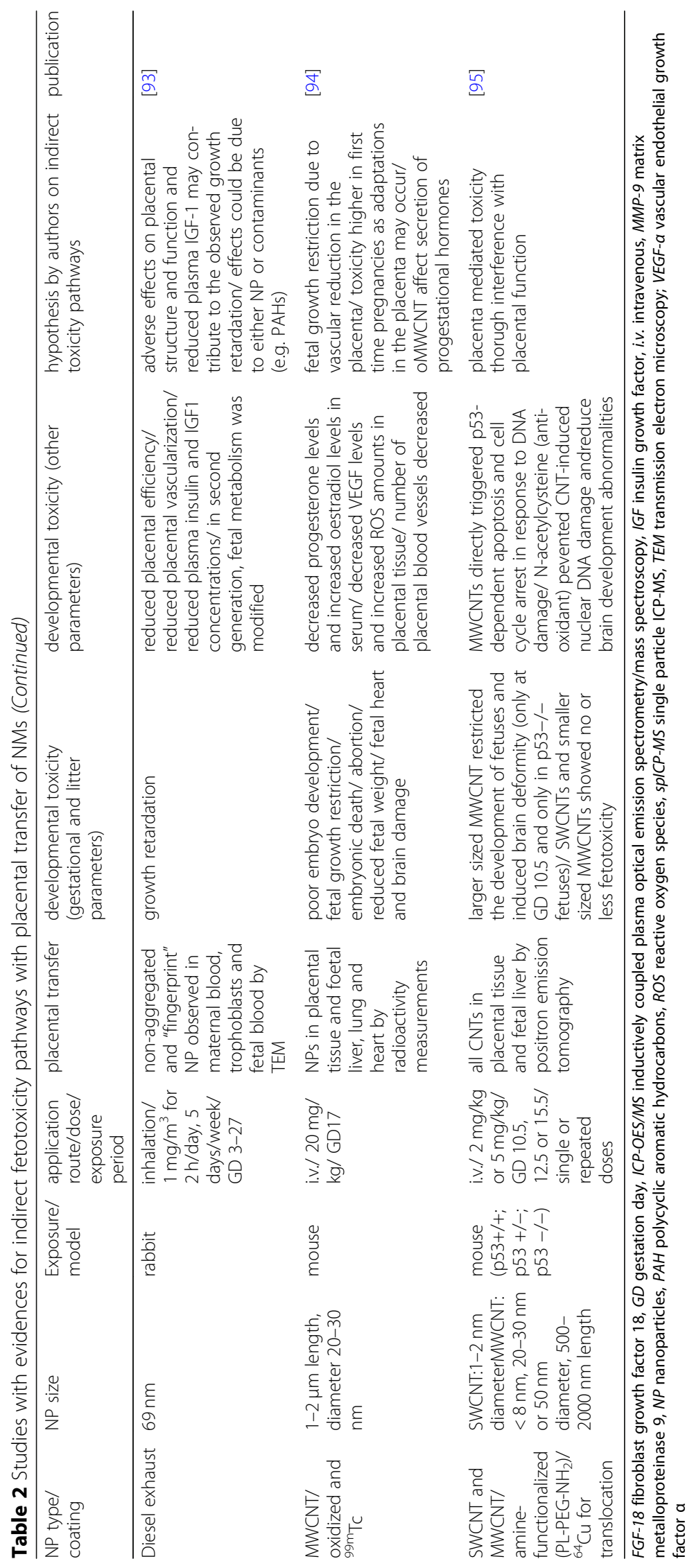




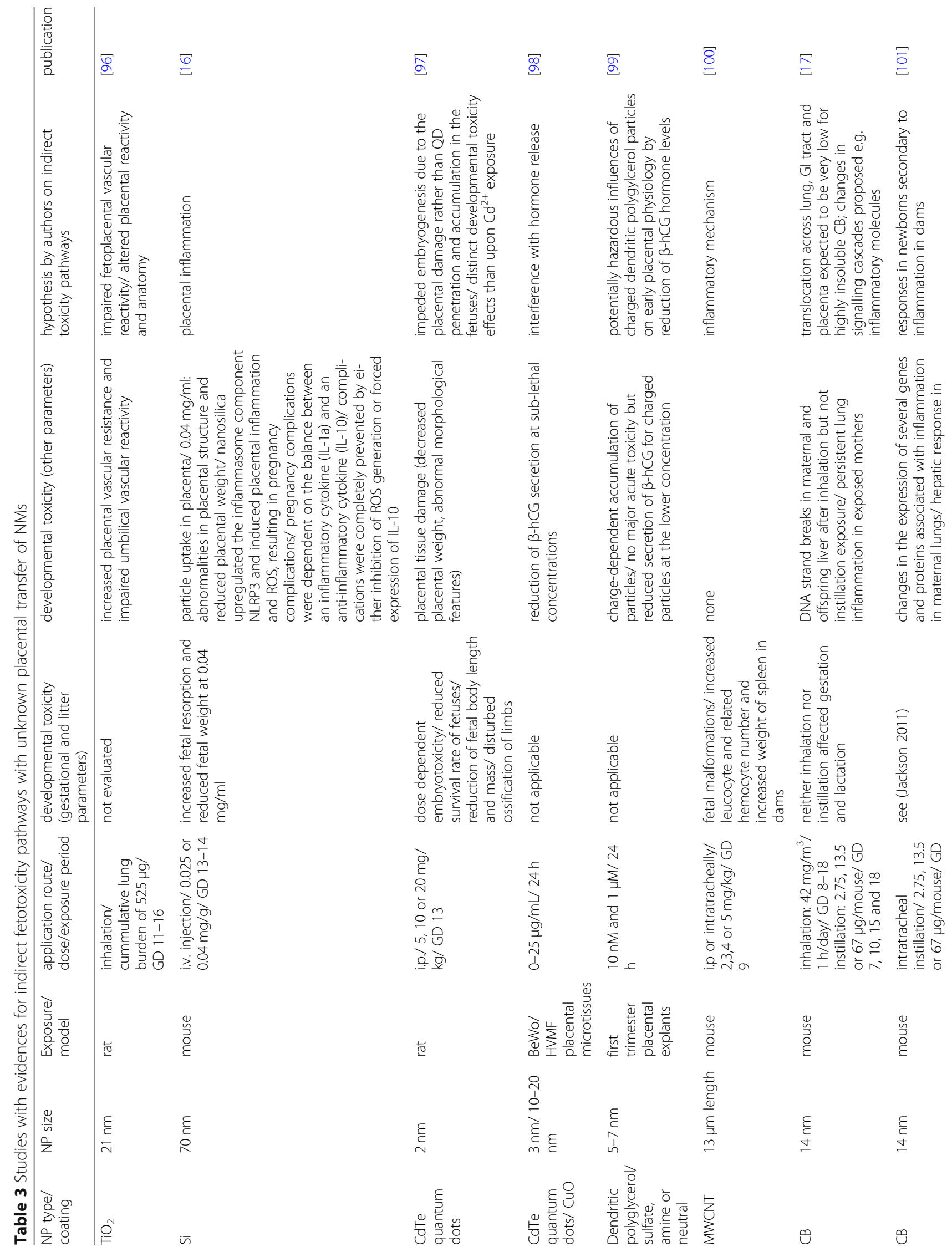




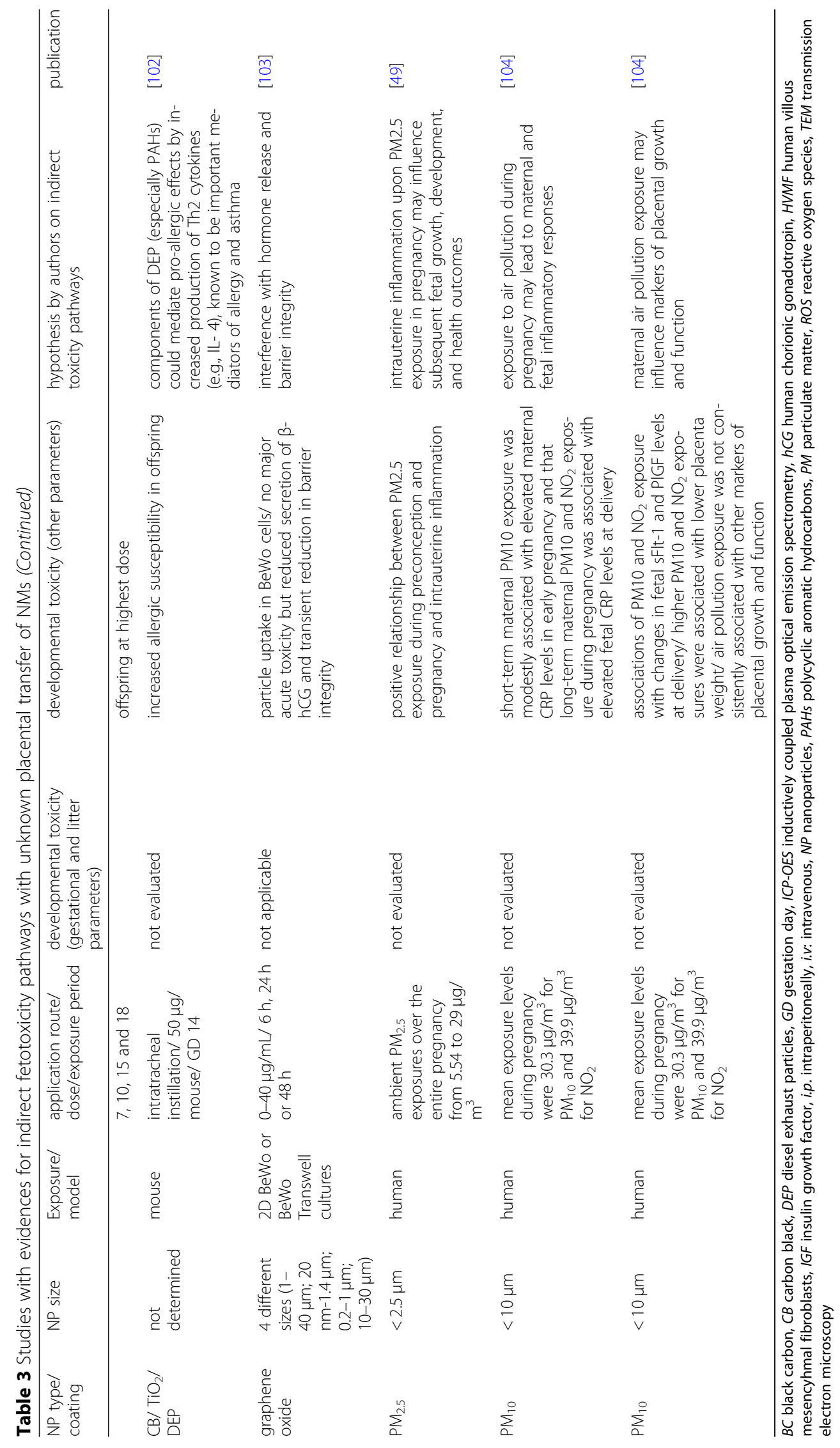


and 16.5 , respectively) and suggested that the underlying mechanisms may involve placental insufficiency with ensuing down-regulation of critical mediators of lung development [76]. Other proposed placenta mediated indirect pathways involve adverse effects of NMs on placental structure and function $[90,92,93,95]$, the release of placental inflammatory mediators [91], reduction in placental vasculature $[93,94]$ and activation of coagulation, complement and oxidative stress in the placenta [90] and disruption of endocrine signaling [91, 93].

\section{Studies with unknown placental particle transfer}

In several studies, placental translocation was not assessed, but the authors nevertheless postulated a role for indirect pathways of developmental toxicity based on observed interference of NMs with maternal organs or placental function (Table 3). Most of these studies did not evaluate gestational and litter parameters, but alterations of these parameters have previously been described following maternal exposure to $\mathrm{TiO}_{2}$ NPs [90], PM [2-4] and DEPs [93]. Injection of $\mathrm{SiO}_{2}$ NPs in pregnant mice $(0.025$ or $0.04 \mathrm{mg} / \mathrm{g}$ body weight on GD 13 and 14) resulted in increased fetal resorption and reduced fetal weight, possibly through particle-induced inflammatory responses in the placental tissue [16]. These complications were entirely prevented by ROS inhibitors or forced expression of IL-10 [16]. Maternal or intrauterine inflammatory pathways were also proposed to mediate developmental toxicity from exposure to air pollution $[49,104]$ carbon black (CB) $[17,101]$ and MWCNTs [100]. Besides inflammatory pathways, interference with the placenta (structure, growth or function/ reactivity) has been suggested to constitute another indirect pathway for developmental toxicity of air pollution particles [104], cadmium telluride (CdTe) QDs [97], $\mathrm{TiO}_{2} \mathrm{NP}$ [96] in vivo or graphene oxide (GO) in vitro [103]. For prenatal exposure to $\mathrm{CB}, \mathrm{TiO}_{2}$ and $\mathrm{CeO}$ NPs (intratracheal instillation: $50 \mu \mathrm{g} /$ mouse on GD 14), Fedulov et al. observed increased allergic susceptibility in the offspring that was proposed to occur due to NM-induced production of Th2 cytokines in maternal lungs [102].

Overall, for all of the three study categories (studies investigating but not detecting placental transfer (Table 1), studies detecting placental transfer (Table 2) and studies with unknown placental transfer (Table 3)), indications of potential indirect toxicity pathways mediated by maternal and/or placental tissue have been identified. Moreover, considering that maternal and placental tissues are probably exposed to NMs at earlier time points and higher dose levels compared to the fetal compartment, extending the focus from direct to indirect effects is of key importance to advance our understanding of risks associated with NM exposure during pregnancy.

\section{Candidate pathways for indirect developmental toxicity}

Developmental toxicity is mostly assessed in experimental animals and often centers on classical gestational and litter parameters. In light of the growing evidence for maternal and placenta mediated developmental toxicity of NMs, it is crucial to perform more comprehensive assessments of placental, maternal and fetal/offspring tissue and organ functions. In this section, we will compile and discuss the different indirect pathways forwarded in the reviewed literature, to outline how NMs may adversely affect developmental outcomes without direct exposure of the fetus to NMs. Although we will mostly describe individual indirect pathways, these are likely interlinked and jointly contribute to adverse fetal outcomes, potentially even in conjunction with direct toxicity pathways.

\section{$N M$-induced oxidative stress and inflammatory responses}

The placenta has a very high turnover of oxygen and ROS are generated continuously, with the main source being the mitochondrial respiratory chain. Overall, the balance between oxidants and antioxidants is vital for maintaining physiological homeostasis. During normal pregnancy conditions, ROS are eliminated by the corresponding and abundant production of antioxidants by the feto-placental unit. If this redox balance is disturbed pathological conditions may emerge [105]. Several types of NMs induce the generation of ROS, either directly or via activation of oxidative enzymatic pathways [106-109]. Excessive amounts of ROS may overwhelm the capacity of the intrinsic antioxidants and result in a condition of oxidative stress [110]. ROS can damage cells by interaction with lipids, proteins and DNA and by induction of inflammation [108, 111]. Placental inflammation is a well-established risk factor for pregnancy and fetal development [112]. If NMs are taken up by placental cells, the subsequent generation of ROS, oxidative stress and inflammation has been hypothesized to represent one indirect mechanistic pathway by which NMs can interfere with placental development and function, and hence, with fetal development $[36,55]$.

Inhaled particles that deposit in the lung alveoli can also locally induce ROS and inflammation. This will often be accompanied by increased transcription of proinflammatory genes and ultimately the production of inflammatory mediators, such as cytokines and acutephase proteins that can become systemically available $[113,114]$. It is increasingly being described that maternal inflammation is a potent modulator of fetal development and that the developing nervous system may be especially sensitive. Maternal inflammation has been proposed to constitute an immune challenge to the fetus that could prime early alterations in the inflammatory response systems and, in turn, disrupt development and 
maturation of the central nervous system and enhance sensitivity to additional stress factors [115]. Maternal inflammation may not necessarily result in fetal inflammation, but the placenta may act as a sensor of maternal inflammation and subsequently adapt to the inflammatory environment and may act both as a target and a producer of inflammatory mediators [116].

Shirasuna et al. (2015) elegantly aimed to investigate if NPs induce pregnancy complications through placental inflammation [16]. Pregnant mice were injected i.v. with $0.04 \mathrm{mg} / \mathrm{kg}$ body weight of $70 \mathrm{~nm}$ silica particles on GD 13 and 14. This exposure increased fetal resorptions, induced placental dysfunction, ROS generation and infiltration with neutrophil granulocytes (3-fold). Also, placental protein levels of several inflammatory cytokines were significantly increased (IL-1 $\beta$, IL-6, TNF- $\alpha$, and CCL2). Pre-treatment with the antioxidant $\mathrm{N}$-acetyl cysteine (NAC) almost completely reversed the placental and fetal effects of the injected NPs, reduced placental ROS levels, cell infiltration and secretion of IL-1 $\beta$ and IL- $1 \alpha$. Findings in specific knock-out mouse strains indicated that the balance between the inflammatory cytokine IL-1 and the anti-inflammatory IL-10 was pivotal for induction of adverse effects. Therefore, the study was repeated with forced expression of IL-10 by injection of adeno-associated virus vectors encoding murine IL-10. Again, the placental and fetal effects of the injected NPs were reversed. Of note, inhibition of placental phagocytosis and hence uptake of NPs significantly blocked IL-1 $\beta$ and IL- $1 \alpha$ secretion, indicating that uptake of NPs into the cells might has been involved in inducing inflammatory pathways in placental cells [16].

The induction of placental ROS by NMs was also addressed by Qi et al. (2014) [94]. Pregnant mice were injected i.v. with $20 \mathrm{mg}$ of oxidized (o-) MWCNTs/kg on GD 17. Exposure increased the ROS levels in placentas, but not in maternal plasma, indicating that the placenta may respond more vigorously or faster to o-MWCNTs than other maternal tissues. The observation of placental implication in developmental toxicity has some resemblance to reports on the effects of SWCNTs, $\mathrm{TiO}_{2}$ and silica NPs $[85,90]$.

Also, other studies have attempted to investigate the degree to which oxidative stress contributes to developmental effects by administering antioxidants alongside the maternal exposure to NMs [55]. Onoda and coworkers investigated the protective effects of antioxidants on the development of reactive astrogliosis in the offspring that had been observed following maternal intranasal instillation of CB NM $(95 \mu \mathrm{g} / \mathrm{kg}$ body weight) on GD 5 and 9 in several previous studies. $\mathrm{N}$-acetyl cysteine or ascorbic acid were administered intraperitoneally to pregnant mice prior to $\mathrm{CB}$ instillation. $\mathrm{N}$-acetyl cysteine partly prevented, whereas ascorbic acid slightly enhanced, astrogliosis in the offspring [117]. Another study investigated the developmental effects of MWCNTs injected intravenously to pregnant p53+/mice $(2 \mathrm{mg} / \mathrm{kg}$ or $5 \mathrm{mg} / \mathrm{kg}$ body weight on GD 10.5, 12.5 or 15.5 as a single or repeated dosis). MWCNTs increased the incidence of brain defects in the offspring and decreased offspring survival rate after birth. The underlying mechanism seemed to involve MWCNTs directly triggering p53-dependent apoptosis and cell cycle arrest in response to DNA damage. Co-injection of an antioxidant markedly decreased the number of fetuses with brain defects, indicating that oxidative stress may be implicated. In this study, MWCNTs were found to distribute to the placenta and fetal liver but were not observed in the fetal brain [95]. Finally, intratracheal instillation of 4-5 mg MWCNTs/kg to pregnant mice on GD 9 was found to induce fetal malformations and to significantly increase maternal leukocyte counts in peripheral blood. At a lower dose of $3 \mathrm{mg} / \mathrm{kg}$, no abnormality occurred. This suggests that maternal inflammation may be contributing to fetal toxicity [100].

Overall, these findings offer evidence of the involvement of oxidative stress in developmental toxicity of NMs. It is, however, important to keep in mind that observation of protection by antioxidants does not specify whether the effects occurred due to oxidative stressinduced directly by particles or indirectly via other mechanistic pathways. In some studies, particle exposure also induced pregnancy complications, such as fetal death, that could be associated with apoptosis and hence generation of increased levels of ROS. Therefore, it is not possible to deduct whether the increases in ROS levels occurred due to particle exposure or pregnancy complications.

\section{NM interference with placental toll-like receptors}

Several cell types express receptors for recognition of pathogen-associated molecular patterns present on the surface of microorganisms. Probably the best-described group of pattern recognition receptors are the TLRs, a group of evolutionary conserved transmembrane proteins [118]. Until now, 11 mammalian TLRs have been defined. TLR 4 is crucial for response to lipopolysaccharide (LPS) and, thereby, to gram-negative bacteria. TLR 2 recognizes a broader array of molecular patterns from bacteria and fungi. Ligand recognition by the TLRs mostly results in the activation of the intracellular signaling pathway of $\mathrm{NFKB}$, ultimately increasing the production of cytokines and antimicrobial factors [119].

The human placenta expresses all of the TLRs, varying in a temporal and spatial manner [120]. Activation of trophoblast TLRs enhances cytokine expression, which may be followed by significant recruitment of immune cells (macrophages, NK cells) to the placenta. TLR- 
activation is associated with negative pregnancy outcomes (preterm labor, fetal loss and preeclampsia), but also plays a role in long-term adverse outcomes in the offspring, such as the function of the immune and central nervous systems [119]. Placental TLRs may, however, also be involved in the protective effects hypothesized to occur in case of "adequate" non-infectious microbial exposure as proposed by the hygiene hypothesis [121].

Accumulating evidence indicate that TLRs might recognize some NMs and activate similar pathways as upon contact with LPS and bacteria [122, 123]. Hence, MWCNTs have been shown to induce DNA damage in human lung epithelial cells due to the activation of TLR 9 and subsequent generation of nitric oxide (NO) [124]. Also, SWCNTs have been reported to provoke chemokine secretion in macrophages via the TLR 2/4MyD88-NFkB signaling pathway [125]. Interestingly, when graphene oxide was tested in the same setup, no such response was elicited, indicating that TLRs may have a differential preference for subgroups of NMs [125]. In silico investigations show that the internal hydrophobic pockets of TLR 4 might be able to bind small-sized carbon nanostructures such as fullerenes and CNTs [126]. TLR 4 has, however, been shown to also recognize non-carbonaceous NMs, such as iron and $\mathrm{TiO}_{2}$ NPs, to promote inflammatory responses [127-129].

In the human placenta, TLR 2 and TLR 4 have been observed to lack in the ST but to be expressed in villous and extravillous trophoblasts, at least during early pregnancy [119]. This could indicate that, at this stage, the placenta responds primarily to pathogen-associated molecular patterns if the ligand has broken through the outer layer [119]. Therefore, NMs would need to be internalized by the trophoblast for TLR activation. Interestingly, several studies in the ex vivo human placenta model and experimental animals report that nanosized particles accumulate in placental tissue [130-132] and that particles can be visualized in trophoblasts [90, 91, 133-135].

Activation of placental TLRs by NMs would implicate the presence of NMs in maternal blood and their uptake/penetration into the ST. Some TLRs do also respond to endogenous molecules via so-called dangerassociated molecular patterns, including, but not restricted to, ROS and proteins released from dead or dying cells [119]. Hence induction of ROS or inflammation by NMs in placental tissue, via direct or indirect pathways, may indirectly activate TLRs.

\section{NM interference with endocrine signaling}

Endocrine signaling pathways are central in mediating physiological and metabolic adaptations required for a successful pregnancy and are orchestrated by the placenta and the maternal endocrine organs (e.g., the pituitary, thyroid and adrenal glands, and the ovaries) [136,
137]. First evidence that NMs can have endocrinedisrupting activity came from studies in non-pregnant individuals, where NMs have been reported to affect levels of both female and male sex hormones in vitro and in vivo (reviewed in [138, 139]). For example, exposure of female and male rats to nickel (Ni) NPs by gavage resulted in altered hormone regulation (FSH and $\mathrm{LH}$ levels were elevated and estradiol lowered in females while testosterone and FSH levels were diminished in males) and induced pathological changes in testes and ovaries (reviewed in [140]). However, it largely remains to be established if NMs might act as endocrine disruptors during pregnancy and how this could potentially affect pregnancy and offspring health later in life.

In pregnancy, one of the critical hormones secreted by the human placenta is human chorionic gonadotropin (hCG) [137]. It supports the function of the corpus luteum, a transient ovarian structure particularly important in the early gestational phase, which secretes ovarian progesterone and estrogens to maintain a successful pregnancy [141]. hCG also regulates the formation of the ST [142, 143], modulates immune responses [143], ensures uterine quiescence [143], promotes angiogenesis of the endometrial spiral arteries [143, 144], and dilates these vessels to enhance maternal blood flow [145]. Due to these various crucial functions of hCG, disturbances in the tightly regulated levels of this hormone could, therefore, increase the risk of adverse pregnancy outcomes [146]. A few in vitro studies using BeWo trophoblast monocultures [103], 3D placental co-culture microtissues (BeWo cells/primary human villous mesenchymal fibroblasts) [98] or first trimester human placental explants [99] showed a significant reduction of hCG release after exposure to $\mathrm{GO}, \mathrm{CdTe}$ and $\mathrm{CuO}$ NPs or dendritic polyglycerol NPs, respectively. This emphasizes that disturbances in hCG release should be considered in developmental toxicity studies.

Also, the steroid hormones estrogen (reviewed in [147]) and progesterone (reviewed in [148]) are indispensable to maintain human pregnancy. Estrogens are essential for vasodilation and local angiogenesis due to their close interaction with angiogenic factors like vascular endothelial growth factor (VEGF) and placental growth factor (PLGF) (reviewed in [147]). Dysregulation of estrogen secretion could, therefore, play a major role in the development of preeclampsia and other adverse conditions during pregnancy. Progesterone is essential for the reproductive process. Altered progesterone secretion has been associated with miscarriage and preterm birth [148]. So far, only a few descriptive studies reporting NM effects on steroid hormone levels in pregnant animals are available. Inhalation of Ag NPs decreased estrogen plasma levels in pregnant mice, but it was unclear if the Ag NP exposure caused the increase in observed 
fetal resorptions [91]. In another study, serum levels of progesterone decreased while estradiol levels increased in pregnant mice injected with MWCNTs [94]. Furthermore, VEGF levels and placental vascularization decreased and were linked with the reported growth restriction in the offspring [94], indicating a potential interconnection between endocrine and vascular pathways.

Other relevant placental and maternal hormones include human placental lactogen, the placental growth factor prolactin, the neuropeptides serotonin, melatonin and oxytocin (reviewed in [136, 137, 141, 149, 150] as well as IGFs (reviewed in [150-153]). Inhalation of DEPs in pregnant rabbits resulted in intra-uterine fetal growth retardation that was accompanied by reduced placental efficiency alongside a decrease in fetal plasma levels of IGF-1 [93], a peptide hormone essential for the regulation of feto-placental growth (reviewed in $[150,153]$ ). However, it remains to be shown in how far the observed changes in fetal IGF-1 levels are responsible for the observed developmental toxicity. Moreover, further clarification is needed if contaminants (e.g. metals or polyaromatic hydrocarbons) associated with the particles could be involved or even be responsible for the adverse effects of DEPs on fetal development.

In summary, the few available studies indicate that NMs might act as endocrine disruptors and interfere with hormonal signaling in pregnancy. The underlying mechanisms are not yet well understood and might include direct effects on hormone biosynthesis and secretion, interference of $\mathrm{NMs}$ with hormone-receptor binding on target cells or with downstream signaling pathways (reviewed in [140]) as well as indirect effects, e.g., via the induction of inflammatory processes, which have been shown to cause endocrine imbalance [154]). Overall, a better understanding of the possible interference of NMs with the endocrine system during pregnancy is still needed and should include long-term studies since endocrine responses often take time before NM-triggered effects are manifested.

\section{NM interference with vascular signaling and utero-placental development and function}

To accommodate the developing fetus, extensive vascular adaptations take place in the uterus and placenta. Maternal blood volume increases around 45\% [155] and uterine placental blood flow increases ten-fold [156]. Maternal blood pressure usually decreases or remains unchanged during pregnancy. This is mainly achieved through a decreased uterine vascular resistance, which is ultimately determined by a combination of an increase in vessel diameter, a reduced vascular tone (vasodilation) and an establishment of the placenta [156]. To ensure that vascular remodeling does neither harm the mother nor the fetus, microcirculatory regulation of blood flow is crucial [157, 158]. Early in pregnancy, the uterine spiral arteries are structurally converted from small diameter arteries into low-resistance large diameter vessels by interaction with the fetal placental extravillous trophoblasts that invade the myometrium and the spiral arteries [159]. Some chemicals have been shown to interfere with vascular remodeling and development of the placenta, thereby impairing oxygen and nutrient delivery to the fetus and ultimately increasing the risk for adverse pregnancy outcomes (reviewed in $[160,161]$ ). Several epidemiological studies have found that components of air pollution, including PM with $2.5 \mu \mathrm{m}$ or less in diameter $\left(\mathrm{PM}_{2.5}\right)$, were associated with increased risk of pregnancy-induced hypertensive disorders [2].

For engineered NMs, studies in experimental animals indicate that maternal NM exposure during gestation interferes with maternal vascular reactivity and placental vascular development and function. Exposure to NMs has been associated with increased tone and contractility of the uterine vasculature [162-166]. In some studies, placentas from exposed pregnant rats were larger, while their offspring were smaller compared to the control group, indicative of effects downstream from the uterine vascular impairment $[163,166]$. As an example, i.v. administration of MWCNTs ( $100 \mu \mathrm{g} / \mathrm{kg}$ body weight) or Ag NPs $(200 \mu \mathrm{g} / \mathrm{rat})$ to pregnant rats at GD 17-19 increased the contractility of the uterine artery. The maternal mesenteric artery and thoracic aorta were unaffected, suggesting that the extensively remodeled and functionally dynamic uterine vasculature is more vulnerable to particle exposure than vascular beds in the adult organism [162, 163]. For Ag NPs, the effects furthermore depended on particle size (only for $10 \mathrm{~nm}$ but not $100 \mathrm{~nm} \mathrm{Ag} \mathrm{NPs)} \mathrm{and} \mathrm{surface} \mathrm{modification} \mathrm{(more}$ substantial effect of citrate compared to PVP-coated Ag NPs) [162]. Using the less invasive inhalation route of exposure, $\mathrm{TiO}_{2}$ NPs have been shown to attenuate both the endothelium-dependent and -independent vessel dilation at the uterine-arteriolar level in both nonpregnant and pregnant rats [164, 165]. This was accompanied by significantly increased plasma levels of the pro-inflammatory factors IL-4 and IL-6 [165], indicating that systemic inflammation could have been implicated in the observed changes. Intratracheally instilled $\mathrm{TiO}_{2}$ NPs induced a systemic Th2 inflammatory response, which was mediated by group II innate lymphoid cells (ILC2) in the lungs. At the same time, endotheliumdependent dilation of the uterine radial arterioles was impaired [167]. IL-33 potently drives the production of Th2-associated cytokines. Treatment with an anti-IL-33 antibody prior to the $\mathrm{TiO}_{2}$ NP exposure attenuated the upregulation of circulating IL-33 levels and improved the endothelium-dependent dilation. Uterine microvascular 
dysfunction may, therefore, arise via activation of ILC2 cells in the lung and the subsequent systemic Th2-dependent inflammation. The study was performed in non-pregnant females, but the mechanisms ought to be also investigated during pregnancy. In another study, inhalation of $\mathrm{TiO}_{2} \mathrm{NPs}$ during pregnancy was found to augment vasoconstriction of the uterine artery in response to Kisspeptin [166]. Kisspeptin is a potent vasoconstrictor and an essential reproductive hormone, which is secreted by the placenta during late pregnancy at 10,000-fold higher levels compared to the non-pregnant state (reviewed in [168]). It is, therefore, possible that $\mathrm{TiO}_{2} \mathrm{NP}$ exposure perturbed the endocrine vascular axis via a kisspeptin-dependent mechanism [166]. Finally, a recent study investigated blood perfusion in placentas from pregnant rats inhaling $\mathrm{TiO}_{2}$ NPs. An endothelium-dependent increase in placental vascular resistance, measured as decreased outflow vein pressure, was observed. NO release plays a crucial role in maintaining the low basal tone of the maternofetal circulation [169] and was therefore hypothesized to be implicated in the signaling causing the decrease in outflow pressure. Increased sensitivity to angiotensin II, a potent vasoconstrictor implicated in preeclampsia [170], was observed in both the placental and umbilical artery [96], also identifying the renin-angiotensin system as a perhaps crucial modulator of tissue tone.

Several studies observed abnormalities in placental development and function following exposure to NMs. Mice treated with $70 \mathrm{~nm}$ silica NPs (nSP70) i.v. $(0.8 \mathrm{mg} /$ mouse on GD 16-17) failed to form spiral artery canals, and blood flow in the fetal vascular sinuses decreased, perhaps due to abnormalities in structure and length of placental villi. The authors suggested that structural and functional changes to the placenta might be a result of the decreased levels of soluble Flt-1 [90], a potent antiangiogenic factor involved in placental vascularization [171]. Orally administrated $\mathrm{TiO}_{2}$ NPs impaired placentation, possibly through the observed dysregulation of placental vascularization, proliferation and apoptosis [48]. Reductions were also observed for the expression of regulators for placental vascularization as well as the number of uterine natural killer ( $\mathrm{uNK}$ ) cells [48], a cell type that plays important roles in remodeling of spiral arteries, control of trophoblast invasion and placental development [172-174]. Injection of QDs (10 or $20 \mathrm{mg} / \mathrm{kg}$ body weight) on GD 13 was associated with placental vascular anomalies, as exposed rats displayed a reduced diameter of the labyrinth and basal zone and necrosis of invasive trophoblasts when examined on GD20 [97]. It is possible that the reduced placental size observed after QD treatment occurred due to the release of cadmium ions, as cadmium is a recognized placental toxicant [175]. A recent mouse study observed (non-particulate) cadmium to up-regulate several inflammatory cytokines in the placenta through the Akt signaling pathway [176], so the mechanisms of developmental toxicity of QD likely differ compared to that of other NMs. Vascular effects of NMs could involve the uptake of particles by extravillous trophoblasts resulting in impaired extravillous trophoblast invasion and vascular remodeling. Hence, a recent in vitro study found uptake of platinum NPs by autophagy to affect extravillous trophoblast functions in exposed cells [177]. Finally, there is also few hints that some NMs might interfere with placental barrier integrity and eventually transport. For instance, GO NPs induced a transient decrease in the integrity of BeWo trophoblast cells in vitro [103]. Blum et al., [83] suggested that developmental toxicity from $\mathrm{CdO} \mathrm{NP}$ inhalation in mice might result from the accumulation of $\mathrm{Cd}$ ions and interference with transport in the placenta since a previous epidemiological study reported that placental Cd can alter the transport of zinc, vitamin B12 and other micronutrients [82]. However, conclusive evidence for NM effects on placental transfer in vivo is still lacking.In conclusion, it is becoming increasingly evident that exposure to NMs can interfere with vascular and placental development, structure and ultimately function, and, therefore, cause severe adverse effects on embryo-fetal development and offspring health. The underlying mechanisms, however, are still to be elucidated.

\section{NM interference with extracellular vesicle signaling}

Cells release extracellular vesicles (EVs) as part of their intercellular communication, with microvesicles (MVs) and exosomes as two main subgroups (reviewed in [178]). EVs contain various molecules such as lipids, nucleic acids and proteins, dependent on their donor cell type and physiological state, and the stimuli that mediated their formation and release [178]. The cargo is considered as information that EVs shuttle from donor to target cells, and even across internal barriers like the blood-brain-barrier [179-181]. Upon contact with the recipient cell, EVs have been shown to initiate different processes depending on their cellular origins, such as an immune response (exosomes originating from B lymphoblastoid or dendritic cells) $[182,183]$ or the transformation of healthy cells to tumor cells (MVs originating from MDAMB231 breast carcinoma and U87 glioma cells) [184].

During pregnancy, EVs are indicated to be involved in critical processes such as maternal-placental vascularization [185] and regulation of the maternal immune response [186]. However, when pregnant women suffer from certain diseases (e.g., preeclampsia and gestational diabetes mellitus), serum EV levels, composition, and function differ [187-192]. Even though it is still unclear, if the altered EV signaling is a contributing factor 
or only a symptom of a pregnancy complication, these studies indicate that EV levels and cargo reflect the physiological state of pregnancy.

Since NMs and EVs are of comparable size and circulate in similar compartments, interactions between them are considered possible, even though only few studies investigated this topic so far. In mice, intratracheal instillation of magnetic iron oxide NPs (MIONs with primary size $\sim 43 \mathrm{~nm}$ ) increased secretion of exosomes in the alveolar region, which contained increased levels of iron, albeit no MIONs could be imaged inside the vesicles by transmission electron microscopy [193, 194]. These exosomes were shown to initiate a systemic Th1-type immune response via direct and indirect $\mathrm{T}$ cell activation [193, 194]. In another study, subtoxic concentrations of $\mathrm{ZnO}$ (primary size $\sim 10 \mathrm{~nm}$ ) and $\mathrm{TiO}_{2} \mathrm{NPs}$ (primary size of $\sim 21 \mathrm{~nm}$ ) did not significantly affect the characteristics of exosomes released by primary human peripheral blood mononuclear cells nor by monocyte-derived dendritic cells, such as size and number. Moreover, NPs were not found attached to the outside or inside of the exosomes [195]. In contrast, $20 \mathrm{~nm}$ sized gold NPs were taken up by human macrophages and found in released exosomes afterwards [196]. Interestingly, the only study investigating effects of NMs on placental-derived EVs demonstrated similar results. Human placental mesenchymal SCs released NP-loaded exosomes after exposure to hollow gold NPs (primary size $40 \mathrm{~nm}$ ). These vesicles were further shown to exclusively migrate to the cell type of origin in vitro [197].

These studies indicate that the release of EVs and their characteristics can be altered by NM exposure, which could systemically affect other tissues in the body. In pregnancy, maternal exposure to NMs may lead to an EV-mediated modulation of cell communication between maternal, placental and fetal tissues. Considering that crucial processes during gestation are facilitated via EVs, disturbances in EV signaling could jeopardize pregnancy, which calls for more extensive investigation of potential influences of NMs on the EV system.

\section{Conclusions and future perspectives}

Indirect pathways probably play a major role in NMinduced developmental toxicity. The placenta likely takes a central position in mediation hereof due to its location at the interface between mother and fetus and the many essential functions it undertakes during pregnancy. An increasing number of studies in experimental animals, in vitro and ex vivo models highlight how NM may exert effects indirectly via induction of maternal and placental oxidative stress and inflammation, activation of placental TLRs, impairment of placental growth, and secretion of placental hormones and vascular factors. Potentially, EVs could play a role in signaling between maternal and fetal organs. The impact of NMs on maternal and placental tissues can ultimately result in pregnancy complications and long-term effects on offspring health, even in the absence of or limited particle transfer across the placenta.

Our understanding of the involved mechanisms is, however, still scarce, and this emphasizes the need for more systematic studies. Comprehensive knowledge of the mechanisms underlying indirect toxicity increases the possibility of identifying triggers of effects and hence to categorize NMs based on shared properties of various materials. This will facilitate the risk assessment of human health effects, and furthermore, the application of a safe-by-design approach in the design of new materials [198]. An important issue is here, whether the effects of NP exposure depends on the existing state of inflammation in the mother, as e.g. asthma and obesity is associated with chronic low-grade inflammation [199]. To our knowledge, this aspect has only been marginally addressed. A study in pregnant mice indicated that LPSinduced intrauterine inflammation can increase the materno-fetal transfer of small AuNPs $(3,13 \mathrm{~nm})$ after i.v. injection at GD 17 [135]. Identification of the key processes in NM induced developmental toxicity will further provide a basis for improvement of in vitro test systems, which are suitable for the screening of a broad range of NMs and allow for the identification of potential hazards to pregnancy. In addition, the application of advanced in vitro models would reduce the use of experimental animals [200].

Apart from identification of the mechanisms underlying developmental toxicity of NMs, the advancement of relevant in vitro systems will profit from the identification of the maternal and fetal organ systems that are most prone to disruption by NMs. To include pathways of indirect toxicity pathways, predictive developmental toxicity assessment of NMs requires the interconnection of multiple in vitro models such as the placenta, maternal tissues and the embryo, either directly in co-cultures $[86,87,201]$, or indirectly via the transfer of conditioned media [88]. The potential of such approaches has been nicely exemplified in some recent studies on the indirect developmental toxicity of $\mathrm{CoCr}$ NPs, revealing DNA damage to occur across the placental barrier in neurons and astrocytes in the absence of NP transfer [86-88]. Recently, a novel microfluidic multitissue platform combining the embryonic SC test and liver microtissues for advanced embryotoxicity testing has been successfully implemented [202]. If the placental barrier could be integrated into such a platform, this might offer another auspicious approach for future developmental toxicity screening of NMs in a dynamic environment. However, the combination of different models often requires compromises and substantial modification of the cultivation 
conditions (e.g., culture medium, cultivation time), and thus, the predictive value of the newly developed multitissue models should be carefully validated. For instance, the use of serum-free media is required for cultivation of embryonic SCs or neural precursor cells to prevent their differentiation, but this might affect the protein corona of NMs, which could alter NM uptake and biological responses in the cells (reviewed in [203, 204]). Another challenge will be to distinguish between direct and indirect toxicity mechanisms for NMs that cross the placental barrier. Here, the comparison of different exposure conditions (e.g., direct versus indirect exposure to NMs as performed by Bhabra et al., (2009) [86]) or depletion of conditioned medium from NMs by centrifugation may allow to better understand the involvement of direct and indirect pathways. Finally, to identify novel mechanisms for indirect developmental toxicity mechanisms of NMs, unbiased omics approaches (e.g., transcriptomics, proteomics, secretomics or epigenomic profiling) should be explored to understand the array of molecular and functional changes that result from NM exposure.

\section{Abbreviations \\ Ag: Silver; BC: B cell; BL: Basal lamina; CB: Carbon black; CdO: Cadmium oxide; CdTe: Cadmium telluride; CeO2: Cerium dioxide; CoCr: Cobalt-chrome; CuO: Copper oxide; DC: Dendritic cell; DEP: Diesel exhaust particle; E: Endothelial; EVs: Extracellular vesicles; F: Fibroblasts; FC: Fetal capillary; GD: Gestational day; Gl: Gastrointestinal; GO: Graphene oxide; HC: Hofbauer cell; hCG: Human chorionic gonadotropin; i.v.: intravenous; IGF: Insulin-like growth factor; ILC2: Innate Iymphoid cell; LPS: Lipopolysaccharide; MIONs: Magnetic iron oxide NPs; MVs: Microvesicles; MWCNT: Multi-walled carbon nanotube; NAC: N-acetyl cysteine; Ni: Nickel; NM: Nanomaterial; NO: nitric oxide; NP: Nanoparticle; nSP70: 70 nm silica NPs; PLAP: Placental- type alkaline phosphatase; PIGF: Placental growth factor; PM: Particulate matter; QDs: Quantum dots; ROS: Reactive oxygen species; SC: Stem cell; sFlt- 1: Soluble FIt-1; SiO2: Silica dioxide; ST: Syncytiotrophoblast; SWCNT: Single- walled carbon nanotube; TC : T cell; TiO2: Titanium dioxide; TLR: Toll-like receptor; UG: Uterine gland; UNK: Uterine natural killer; VEGF: Vascular endothelial growth factor; ZnO: Zinc oxide}

\section{Authors' contributions}

All authors contributed to the design and concept of this article and drafted the manuscript. All authors critically revised the manuscript. All authors read and approved the final manuscript.

\section{Funding}

This research is supported by funding from the Swiss National Science Foundation (grant no 31003A_179337). Karin Sørig Hougaard was supported by the Danish Working Environment Research Fund (Danish Centre for Nanosafety II) and Signe Schmidt KjøIner Hansen was supported by a grant from the Independent Research Fund Denmark.

\section{Availability of data and materials}

Not applicable.

\section{Ethics approval and consent to participate}

Not applicable.

\section{Consent for publication}

Not applicable.

\section{Competing interests}

The authors declare that they have no competing interests.

\section{Author details}

'Laboratory for Particles-Biology Interactions, Empa, Swiss Federal Laboratories for Materials Science and Technology, Empa, Lerchenfeldstrasse 5, 9014 St.Gallen, Switzerland. ${ }^{2}$ National Research Centre for the Working Environment, Copenhagen, Denmark. ${ }^{3}$ Biotech Research and Innovation Centre, University of Copenhagen, Copenhagen, Denmark. ${ }^{4}$ Department of Public Health, University of Copenhagen, Copenhagen, Denmark.

Received: 25 March 2020 Accepted: 14 June 2020

Published online: 11 July 2020

\section{References}

1. Barouki R, Gluckman PD, Grandjean P, Hanson M, Heindel JJ. Developmental origins of non-communicable disease: implications for research and public health. Environ Health. 2012:11:42.

2. Pedersen M, Stayner L, Slama R, Sørensen M, Figueras FJ, Nieuwenhuijsen $M$, et al. Ambient air pollution and pregnancy-induced hypertensive disorders: A systematic review and meta-analysis. Hypertension. 2014;64(3): 494-500.

3. Dadvand P, Parker J, Bell ML, Bonzini M, Brauer M, Darrow LA, et al. Materna exposure to particulate air pollution and term birth weight: a multi-country evaluation of effect and heterogeneity. Environ Health Perspect. 2013;121: 267-373.

4. Fleischer NL, Merialdi M, van Donkelaar A, Vadillo-Ortega F, Martin RV Betran AP, et al. Outdoor air pollution, preterm birth, and low birth weight: analysis of the world health organization global survey on maternal and perinatal health. Environ Health Perspect. 2014;122:425-30.

5. Bové $H$, Bongaerts E, Slenders E, Bijnens EM, Saenen ND, Gyselaers W, et al. Ambient black carbon particles reach the fetal side of human placenta. Nat Commun. 2019;10:1-7.

6. Rashidi L, Khosravi-Darani K. The applications of nanotechnology in food industry. Crit Rev Food Sci Nutr. 2011;51:723-30.

7. Weir A, Westerhoff P, Fabricius L, Hristovski K, von Goetz N. Titanium dioxide nanoparticles in food and personal care products. Environ Sci Technol. 2012:46:2242

8. Raj S, Jose S, Sumod US, Sabitha M. Nanotechnology in cosmetics: Opportunities and challenges. J Pharm Bioallied Sci. 2012:4:186-93.

9. van der Meel R, Sulheim E, Shi Y, Kiessling F, Mulder WJM, Lammers T. Smart cancer nanomedicine. Nat Nanotechnol. 2019;14:1007-17.

10. Salata OV. Applications of nanoparticles in biology and medicine. J Nanobiotechnol. 2004;2:3.

11. Mazzola L. Commercializing nanotechnology. Nat Biotechnol. 2003;21:1137.

12. Buerki-Thurnherr T, Schaepper K, Aengenheister L, Wick P. Developmental toxicity of nanomaterials: Need for a better understanding of indirect effects. Chem Res Toxicol. 2018;31(8):641-2.

13. Philbrook NA, Winn LM, Afrooz ARMN, Saleh NB, Walker VK. The effect of $\mathrm{TiO} 2$ and $\mathrm{Ag}$ nanoparticles on reproduction and development of Drosophila melanogaster and CD-1 mice. Toxicol Appl Pharmacol. 2011;257:429-36.

14. Shimizu M, Tainaka H, Oba T, Mizuo K, Umezawa M, Takeda K. Maternal exposure to nanoparticulate titanium dioxide during the prenatal period alters gene expression related to brain development in the mouse. Part Fibre Toxicol. 2009;6:2-9.

15. Takeda K, Suzuki K, Ishihara A, Kubo-Irie M, Fujimoto R, Tabata M, et al. Nanoparticles transferred from pregnant mice to their offspring can damage the genital and cranial nerve systems. J Heal Sci. 2009;55:95-102.

16. Shirasuna K, Usui F, Karasawa T, Kimura H, Kawashima A, Mizukami H, et al. Nanosilica-induced placental inflammation and pregnancy complications: different roles of the inflammasome components NLRP3 and ASC. Nanotoxicology. 2015:9:554-67.

17. Jackson P, Hougaard KS, Boisen AMZ, Jacobsen NR, Jensen KA, Møller $P$, et al. Pulmonary exposure to carbon black by inhalation or instillation in pregnant mice: effects on liver DNA strand breaks in dams and offspring. Nanotoxicology. 2012;6:486-500.

18. Rollerova E, Tulinska J, Liskova A, Kuricova M, Kovriznych J, Mlynarcikova A et al. Titanium dioxide nanoparticles: some aspects of toxicity/focus on the development. Endocr Regul. 2015;49:97-112.

19. Fu PP, Xia Q, Hwang H-M, Ray PC, Yu H. Mechanisms of nanotoxicity: generation of reactive oxygen species. J Food Drug Anal. 2014;22:64-75.

20. Donaldson K, MacNee W. Potential mechanisms of adverse pulmonary and cardiovascular effects of particulate air pollution (PM10). Int J Hyg Environ Health. 2001;203:411-5. 
21. Mohorovic L. First two months of pregnancy - critical time for preterm delivery and low birthweight caused by adverse effects of coal combustion toxics. Early Hum Dev. 2004;80:115-23.

22. Risom L, Møller P, Loft S. Oxidative stress-induced DNA damage by particulate air pollution. Mutat Res Mol Mech Mutagen. 2005;592:119-37.

23. Puisney C, Baeza-Squiban A, Boland S. Mechanisms of uptake and translocation of nanomaterials in the lung BT - cellular and molecular toxicology of nanoparticles. In: Saquib Q, Faisal M, Al-Khedhairy AA, Alatar AA, editors. Cham: Springer International Publishing; 2018. 21-36.

24. Braakhuis HM, Kloet SK, Kezic S, Kuper F, Park MVDZDZ, Bellmann S, et al. Progress and future of in vitro models to study translocation of nanoparticles. Arch Toxicol. 2015;89:1469-95.

25. Bouwmeester $H$, van der Zande $M$, Jepson MA. Effects of food-borne nanomaterials on gastrointestinal tissues and microbiota. WIREs Nanomedicine and Nanobiotechnology. 2018;10:e1481.

26. Muoth C, Aengenheister L, Kucki M, Wick P, Buerki-Thurnherr T. Nanoparticle transport across the placental barrier: pushing the field forward! Nanomedicine Future Medicine. 2016;11:941-57.

27. Pietroiusti A, Campagnolo L, Fadeel B. Interactions of engineered nanoparticles with organs protected by internal biological barriers. Small. 2013;9:1557-72.

28. Kermanizadeh A, Balharry D, Wallin H, Loft S, Møller P. Nanomaterial translocation-the biokinetics, tissue accumulation, toxicity and fate of materials in secondary organs-a review. Crit Rev Toxicol. 2015;45: 837-72.

29. Landsiedel R, Fabian E, Ma-Hock L, Wohlleben W, Wiench K, Oesch F, et al. Toxico-/biokinetics of nanomaterials. Arch Toxicol. 2012;86:1021-60.

30. Campbell CSJ, Contreras-Rojas LR, Delgado-Charro MB, Guy RH. Objective assessment of nanoparticle disposition in mammalian skin after topical exposure. J Control Release. 2012;162:201-7.

31. Larese Filon F, Mauro M, Adami G, Bovenzi M, Crosera M. Nanoparticles skin absorption: new aspects for a safety profile evaluation. Regul Toxicol Pharmacol. 2015;72:310-22.

32. Celá P, Veselá B, Matalová E, Večeřa Z, Buchtová M. Embryonic toxicity of nanoparticles. Cells Tissues Organs. 2014;199:1-23.

33. Hougaard KS, Fadeel B, Gulumian M, Kagan VE, Savolainen KM. Developmental toxicity of engineered nanoparticles. In: Gupta RCBT-R, DT, editors. Reprod Dev Toxicol. San Diego: Academic Press; 2011. p. 269-90.

34. Kuhlbusch TAJ, Wijnhoven SWP, Haase A. Nanomaterial exposures for worker, consumer and the general public. Nanolmpact. 2018;10:11-25. https://doi.org/10.1016/j.impact.2017.11.003.

35. Kuhlbusch TAJ, Wijnhoven SWP, Haase A. Nanomaterial exposures for worker, consumer and the general public. 2018;10:11-25. https://doi.org/10. 1016/j.impact.2017.11.003.

36. Hougaard KS, Campagnolo L, Chavatte-Palmer P, Tarrade A, RousseauRalliard D, Valentino $S$, et al. A perspective on the developmental toxicity of inhaled nanoparticles. Reprod Toxicol. 2015;56:118-40.

37. Europäische Agentur für Sicherheit und Gesundheitsschutz am Arbeitsplatz. Directive 92/85/EEC - pregnant workers [Internet]. [cited 2020 Feb 25]. Available from: https://osha.europa.eu/de/legislation/directives/10.

38. Sayle AE, Wilcox AJ, Weinberg CR, Baird DD. A prospective study of the onset of symptoms of pregnancy. J Clin Epidemiol. 2002;55:676-80.

39. European Agency for Safety and Health at Work. State of the art report on reproductive toxicants. 2016.

40. Yang $Y$, Doudrick $K$, Bi X, Hristovski $K$, Herckes $P$, Westerhoff $P$, et al. Characterization of food-grade titanium dioxide: the presence of nanosized particles. Environ Sci Technol. 2014:48:6391-400.

41. Peters RJB, Van Bemmel G, Herrera-Rivera Z, Helsper HPFG, Marvin HJP, Weigel $\mathrm{S}$, et al. Characterization of titanium dioxide nanoparticles in food products: analytical methods to define nanoparticles. J Agric Food Chem. 2014;62:6285-93.

42. Winkler HC, Notter T, Meyer U, Naegeli $\mathrm{H}$. Critical review of the safety assessment of titanium dioxide additives in food. J Nanobiotechnol. 2018;16:51.

43. Nohynek GJ, Dufour EK, Roberts MS. Nanotechnology, cosmetics and the skin: is there a health risk? Skin Pharmacol Physiol. 2008;21:136-49.

44. Fournier SB, D'Errico JN, Stapleton PA. Engineered nanomaterial applications in perinatal therapeutics. Pharmacol Res. 2018;130:36-43.

45. Keelan JA, Leong JW, Ho D, lyer KS. Therapeutic and safety considerations of nanoparticle-mediated drug delivery in pregnancy. Nanomedicine. 2015; 10:2229-47.
46. King A, Ndifon C, Lui S, Widdows K, Kotamraju VR, Agemy L, et al. Tumorhoming peptides as tools for targeted delivery of payloads to the placenta. Sci Adv. 2016;2:e1600349.

47. Paul JW, Hua S, llicic M, Tolosa JM, Butler T, Robertson S, et al. Drug delivery to the human and mouse uterus using immunoliposomes targeted to the oxytocin receptor. Am J Obstet Gynecol. 2017;216:283 e1-283.e14.

48. Zhang L, Xie X, Zhou Y, Yu D, Deng Y, Ouyang J, et al. Gestational exposure to titanium dioxide nanoparticles impairs the placentation through dysregulation of vascularization, proliferation and apoptosis in mice. Int J Nanomedicine. 2018;13:777-89.

49. Massa NR, Guangyun M, Xingyou Z, Xiumei H, Zhu C, Sampankanpanich SC, et al. Intrauterine inflammation and maternal exposure to ambient PM2.5 during preconception and specific periods of pregnancy: the Boston birth cohort. Environ Health Perspect. 2016;124:1608-15.

50. Riediker M, Zink D, Kreyling W, Oberdörster G, Elder A, Graham U, et al. Particle toxicology and health - where are we? Part Fibre Toxicol. 2019;16:19.

51. Ho D, Leong JW, Crew RC, Norret M, House MJ, Mark PJ, et al. Maternalplacental-fetal biodistribution of multimodal polymeric nanoparticles in a pregnant rat model in mid and late gestation. Sci Rep. 2017;7:2866.

52. Buerki-Thurnherr T, von Mandach U, Wick P, Von Mandach U, Wick P. Knocking at the door of the unborn child: engineered nanoparticles at the human placental barrier. Swiss Med Wkly. 2012;142:1-9.

53. Pietroiusti A, Vecchione L, Malvindi MA, Aru C, Massimiani M, Camaioni A, et al. Relevance to investigate different stages of pregnancy to highlight toxic effects of nanoparticles: The example of silica. Toxicol Appl Pharmacol. 2018;342:60-8.

54. Teng C, Jia J, Wang Z, Sharma VK, Yan B. Size-dependent maternal-fetal transfer and fetal developmental toxicity of $\mathrm{ZnO}$ nanoparticles after oral exposures in pregnant mice. Ecotoxicol Environ Saf. 2019;182:109439.

55. Ema M, Hougaard KS, Kishimoto A, Honda K. Reproductive and developmental toxicity of carbon-based nanomaterials: a literature review. Nanotoxicology. 2016;10:391-412.

56. Ema M, Gamo M, Honda K. Developmental toxicity of engineered nanomaterials in rodents. Toxicol Appl Pharmacol. 2016;299:47-52.

57. Ema M, Naya M, Horimoto M, Kato H. Developmental toxicity of diesel exhaust: A review of studies in experimental animals. Reprod Toxicol. 2013;42:1-17.

58. Larsen PB, Mørc TA, Andersen DN, Hougaard KS. A critical review of studies on the reproductive and developmental toxicity of nanomaterials. European Chemicals Agency. 2020.

59. Chavatte-Palmer P, Guillomot M. Comparative implantation and placentation. Gynecol Obstet Invest. 2007:64(3);166-74.

60. Woods L, Perez-Garcia V, Hemberger M. Regulation of placental development and its impact on fetal growth - New insights from mouse models. Front. Endocrinol. (Lausanne). 2018;9:570.

61. Syme MR, Paxton JW, Keelan JA. Drug transfer and metabolism by the human placenta. Clin Pharmacokinet. 2004:43:487-514.

62. Huppertz B. The anatomy of the normal placenta. J Clin Pathol. 2008;61: 1296 LP-1302.

63. Kibschull M, Gellhaus A, Winterhager E. Analogous and unique functions of connexins in mouse and human placental development. Placenta. 2008:29:848-54.

64. Aplin JD, Jones CJP, Harris LK. Adhesion molecules in human trophoblast a review. I Villous trophoblast. Placenta. 2009;30:293-8.

65. Włoch S, Pałasz A, Kamiński M. Active and passive transport of drugs in the human placenta. Ginekol Pol. 2009;80:772-7.

66. Gathiram P, Moodley J. Pre-eclampsia: its pathogenesis and pathophysiolgy. Cardiovasc J Afr. 2016;27:71-8.

67. Gasperowicz M, Otto F. The notch signalling pathway in the development of the mouse placenta. Placenta. 2008;29:651-9.

68. Burton GJ, Fowden AL, Thornburg KL. Placental origins of chronic disease. Physiol Rev. 2016;96:1509-65.

69. Hradecký P, Mossman HW. Vertebrate fetal membranes: Comparative ontogeny and morphology; Evolution; Phylogenetic significance; Basic functions; Research opportunities. J Zoo Anim Med. 1987;18:55.

70. Dilworth MR, Sibley CP. Review: transport across the placenta of mice and women. Placenta. 2013;34:S34-9.

71. Schmidt A, Morales-Prieto DM, Pastuschek J, Fröhlich K, Markert UR. Only humans have human placentas: molecular differences between mice and humans. J Reprod Immunol. 2015;108:65-71.

72. Ganguly K, Ettehadieh D, Upadhyay S, Takenaka S, Adler T, Karg E, et al. Early pulmonary response is critical for extra-pulmonary carbon nanoparticle 
mediated effects: comparison of inhalation versus intra-arterial infusion exposures in mice. Part Fibre Toxicol. 2017;14:1-17.

73. Mahler GJ, Esch MB, Tako E, Southard TL, Archer SD, Glahn RP, et al. Oral exposure to polystyrene nanoparticles affects iron absorption. Nat Nanotechnol. 2012;7:264.

74. Moreno-Olivas F, Tako E, Mahler GJ. ZnO nanoparticles affect nutrient transport in an in vitro model of the small intestine. Food Chem Toxicol. 2019;124:112-27.

75. Notter T, Aengenheister L, Weber-Stadlbauer U, Naegeli H, Wick P, Meyer U, et al. Prenatal exposure to TiO2 nanoparticles in mice causes behavioral deficits with relevance to autism spectrum disorder and beyond. Trans| Psychiatry. 2018;8:193.

76. Paul E, Franco-Montoya ML, Paineau E, Angeletti B, Vibhushan S, Ridoux A, et al. Pulmonary exposure to metallic nanomaterials during pregnancy irreversibly impairs lung development of the offspring. Nanotoxicology. 2017;11:484-95.

77. Hougaard KS, Jackson P, Jensen KA, et al. Effects of prenatal exposure to surface-coated nanosized titanium dioxide (UV-Titan). A study in mice [published correction appears in Part Fibre Toxicol. 2011;8:14]. Part Fibre Toxicol. 2010;7:16. https://doi.org/10.1186/1743-8977-7-16.

78. Adamcakova-Dodd A, Monick MM, Powers LS, et al. Effects of prenatal inhalation exposure to copper nanoparticles on murine dams and offspring. Part Fibre Toxicol. 2015;12:30. https://doi.org/10.1186/s12989015-0105-5.

79. Bush PG, Mayhew TM, Abramovich DR, Aggett PJ, Burke MD, Page KR. Maternal cigarette smoking and oxygen diffusion across the placenta. Placenta. 2000;21:824-33.

80. Mushtaq T, Bijman P, Ahmed SF, Farquharson C. Insulin-like growth factoraugments chondrocyte hypertrophy and reverses glucocorticoid-mediated growth retardation in fetal mice metatarsal cultures. Endocrinology. 2004; 145:2478-86.

81. Nagaya K, Makita Y, Taketazu G, Okamoto T, Nakamura E, Hayashi T, et al. Paternal allele of IGF2 gene haplotype CTG is associated with fetal and placental growth in japanese. Pediatr Res. 2009;66:135-9.

82. Danielsson BR, Dencker L. Effects of cadmium on the placental uptake and transport to the fetus of nutrients. Biol Res Pregnancy Perinatol. 1984;5:93-101.

83. Blum JL, Xiong JQ, Hoffman C, Zelikoff JT. Cadmium associated with inhaled cadmium oxide nanoparticles impacts fetal and neonatal development and growth. Toxicol Sci. 2012;126:478-86.

84. Philbrook NA, Walker VK, Afrooz ARMN, Saleh NB, Winn LM. Investigating the effects of functionalized carbon nanotubes on reproduction and development in Drosophila melanogaster and CD-1 mice. Reprod Toxicol. 2011:32:442-8

85. Pietroiusti A, Massimiani M, Fenoglio I, Colonna M, Valentini F, Palleschi G, et al. Low doses of pristine and oxidized single-wall carbon nanotubes affect mammalian embryonic development. ACS Nano. 2011;5:4624-33.

86. Bhabra G, Sood A, Fisher B, Cartwright L, Saunders M, Evans WH, et al. Nanoparticles can cause DNA damage across a cellular barrier. Nat Nanotechnol. 2009;4:876-83.

87. Sood A, Salih S, Roh D, Lacharme-Lora L, Parry M, Hardiman B, et al. Signalling of DNA damage and cytokines across cell barriers exposed to nanoparticles depends on barrier thickness. Nat Nanotechnol. 2011;6:824-33.

88. Hawkins SJ, Crompton LA, Sood A, Saunders M, Boyle NT, Buckley A, et al, Nanoparticle-induced neuronal toxicity across placental barriers is mediated by autophagy and dependent on astrocytes. Nat. Nanotechnol. 2018;13(5): 427-33.

89. Ye L, Hu R, Liu L, Liu J, Liu J, Chen H, et al. Comparing semiconductor Nanocrystal toxicity in pregnant mice and non-human primates Nanotheranostics. 2018;3:54-65.

90. Yamashita K, Yoshioka Y, Higashisaka K, Mimura K, Morishita Y, Nozaki M, et al. Silica and titanium dioxide nanoparticles cause pregnancy complications in mice. Nat Nanotechnol. 2011;6:321-8.

91. Campagnolo L, Massimiani M, Vecchione L, Piccirilli D, Toschi N, Magrini A et al. Silver nanoparticles inhaled during pregnancy reach and affect the placenta and the foetus. Nanotoxicology. 2017;11:687-98.

92. Vidmar J, Loeschner K, Correia M, Larsen EH, Manser P, Wichser A, et al. Translocation of silver nanoparticles in the: ex vivo human placenta perfusion model characterized by single particle ICP-MS. Nanoscale. 2018;10: 11980-91.

93. Valentino SA, Tarrade A, Aioun J, Mourier E, Richard C, Dahirel M, et al. Maternal exposure to diluted diesel engine exhaust alters placental function and induces intergenerational effects in rabbits. Part. Fibre Toxicol. 2016; 13(1):1.

94. Qi W, Bi J, Zhang X, Wang JJ, Wang JJ, Liu P, et al. Damaging effects of multi-walled carbon nanotubes on pregnant mice with different pregnancy times. Sci Rep. 2014;4:1-13.

95. Huang X, Zhang F, Sun X, Choi K-Y, Niu G, Zhang G, et al. The genotypedependent influence of functionalized multiwalled carbon nanotubes on fetal development. Biomaterials. 2014;35:856-65.

96. Abukabda AB, Bowdridge EC, McBride CR, Batchelor TP, Goldsmith WT, Garner KL, et al. Maternal titanium dioxide nanomaterial inhalation exposure compromises placental hemodynamics. Toxicol Appl Pharmacol. 2019;367: 51-61.

97. Zalgeviciene V, Kulvietis V, Bulotiene D, Zurauskas E, Laurinaviciene A, Skripka A, et al. Quantum dots mediated embryotoxicity via placental damage. Reprod Toxicol. 2017;73:222-31.

98. Muoth C, Wichser A, Monopoli M, Correia M, Ehrlich N, Loeschner K, et al. A 3D co-culture microtissue model of the human placenta for nanotoxicity assessment. Nanoscale. 2016;8:17322-32.

99. Juch H, Nikitina L, Reimann S, Gauster M, Dohr G, Obermayer-Pietsch B, et al. Dendritic polyglycerol nanoparticles show charge dependent biodistribution in early human placental explants and reduce hCG secretion. Nanotoxicology. 2018;12:90-103.

100. Fujitani T, Ohyama K, Hirose A, Nishimura T, Nakae D, Ogata A. Teratogenicity of multi-wall carbon nanotube (MWCNT) in ICR mice. $J$ Toxicol Sci. 2012;37:81-9.

101. Jackson P, Hougaard KS, Vogel U, Wu D, Casavant L, Williams A, et al. Exposure of pregnant mice to carbon black by intratracheal instillation: Toxicogenomic effects in dams and offspring. Mutat Res. 2012;745:73-83.

102. Fedulov AV, Leme A, Yang Z, Dahl M, Lim R, Mariani TJ, et al. Pulmonary exposure to particles during pregnancy causes increased neonatal asthma susceptibility. Am J Respir Cell Mol Biol. 2008;38:57-67.

103. Kucki M, Aengenheister L, Diener L, Rippl AV, Vranic S, Newman L, et al. Impact of graphene oxide on human placental trophoblast viability, functionality and barrier integrity. 2D Mater. 2018:5.

104. van den Hooven EH, Pierik FH, de Kluizenaar Y, Hofman A, van Ratingen SW, Zandveld PYJ, et al. Air pollution exposure and markers of placental growth and function: The generation R study. Environ Health Perspect. 2012;120: 1753-9.

105. Wu F, Tian F-J, Lin Y, Xu W-M. Oxidative stress: placenta function and dysfunction. Am J Reprod Immunol. 2016;76:258-71.

106. Møller P, Jacobsen NR, Folkmann JK, Danielsen PH, Mikkelsen L, Hemmingsen JG, et al. Role of oxidative damage in toxicity of particulates. Free Radic Res. 2010;44:1-46.

107. Shvedova AA, Pietroiusti A, Fadeel B, Kagan VE. Mechanisms of carbon nanotube-induced toxicity: focus on oxidative stress. Toxicol Appl Pharmacol. 2012;261:121-33.

108. Nel A, Xia T, Mädler L, Li N. Toxic potential of materials at the nanolevel. Science. 2006:311:622-7.

109. Roesslein M, Hirsch C, Kaiser J-P, Krug HF, Wick P. Comparability of in vitro tests for bioactive nanoparticles: a common assay to detect reactive oxygen species as an example. Int J Mol Sci. 2013;14:24320-37.

110. Lugrin J, Rosenblatt-Velin N, Parapanov R, Liaudet L. The role of oxidative stress during inflammatory processes. Biol Chem. 2014;395:203-30.

111. Braakhuis HM, Park MVDZ, Gosens I, De Jong WH, Cassee FR. Physicochemical characteristics of nanomaterials that affect pulmonary inflammation. Part Fibre Toxicol. 2014:11:18

112. Kim CJ, Romero R, Chaemsaithong P, Kim J-S. Chronic inflammation of the placenta: definition, classification, pathogenesis, and clinical significance. Am J Obstet Gynecol. 2015;213:S53-69.

113. Pope CA 3rd, Bhatnagar A, McCracken JP, Abplanalp W, Conklin DJ, OToole T. Exposure to fine particulate air pollution is associated With endothelial injury and systemic inflammation. Circ Res. 2016;1 19:1204-14.

114. Poulsen SS, Knudsen KB, Jackson P, Weydahl IEK, Saber AT, Wallin H, et al. Multi-walled carbon nanotube-physicochemical properties predict the systemic acute phase response following pulmonary exposure in mice. PLoS One. 2017;12:e0174167.

115. Meyer U. Prenatal poly(l:C) exposure and other developmental immune activation models in rodent systems. Biol Psychiatry. 2014;75:307-15.

116. Pantham P, Aye ILMH, Powell TL. Inflammation in maternal obesity and gestational diabetes mellitus. Placenta. 2015;36:709-15. 
117. Onoda A, Takeda K, Umezawa M. Pretreatment with N-acetyl cysteine suppresses chronic reactive astrogliosis following maternal nanoparticle exposure during gestational period. Nanotoxicology. 2017;11:1012-25.

118. Botos I, Segal DM, Davies DR. The structural biology of toll-like receptors. Structure. 2011;19:447-59.

119. Koga K, Izumi G, Mor G, Fujii T, Osuga Y. Toll-like receptors at the maternalfetal interface in normal pregnancy and pregnancy complications. Am J Reprod Immunol. 2014;72:192-205.

120. Pudney J, He X, Masheeb Z, Kindelberger DW, Kuohung W, Ingalls RR. Differential expression of toll-like receptors in the human placenta across early gestation. Placenta. 2016;46:1-10.

121. Conrad ML, Ferstl R, Teich R, Brand S, Blümer N, Yildirim AO, et al. Maternal TLR signaling is required for prenatal asthma protection by the nonpathogenic microbe Acinetobacter Iwoffii F78. J Exp Med. 2009;206:2869-77.

122. Fadeel B. Hide and seek: Nanomaterial interactions with the immune system. Front. Immunol. 2019;10:133.

123. Hansen JS, Rosengren TS, Johansson HKL, Barfod KK, Larsen ST, Sørli JB, et al. Pre-conceptional exposure to multiwalled carbon nanotubes suppresses antibody production in mouse offspring. Nanotoxicology. 2020

124. Hiraku Y, Guo F, Ma N, Yamada T, Wang S, Kawanishi S, et al. Multi-walled carbon nanotube induces nitrative DNA damage in human lung epithelial cells via HMGB1-RAGE interaction and toll-like receptor 9 activation. Part Fibre Toxicol. 2016;13:16.

125. Mukherjee SP, Bondarenko O, Kohonen P, Andón FT, Brzicová T, Gessner I, et al. Macrophage sensing of single-walled carbon nanotubes via Toll-like receptors. Sci Rep. 2018;8:1115.

126. Turabekova M, Rasulev B, Theodore M, Jackman J, Leszczynska D, Leszczynski J. Immunotoxicity of nanoparticles: a computational study suggests that CNTs and C60 fullerenes might be recognized as pathogens by toll-like receptors. Nanoscale. 2014;6:3488-95.

127. Mano SS, Kanehira K, Taniguchi A. Comparison of cellular uptake and inflammatory response via toll-like receptor 4 to lipopolysaccharide and titanium dioxide nanoparticles. Int J Mol Sci. 2013;14:13154-70.

128. Chen $\mathrm{P}$, Kanehira K, Taniguchi A. Role of toll-like receptors 3, 4 and 7 in cellular uptake and response to titanium dioxide nanoparticles. Sci Technol Adv Mater. 2013;14:15008.

129. Jin R, Liu L, Zhu W, Li D, Yang L, Duan J, et al. Iron oxide nanoparticles promote macrophage autophagy and inflammatory response through activation of toll-like Receptor-4 signaling. Biomaterials. 2019;203:23-30.

130. Aengenheister L, Batbajar Dugershaw B, Manser P, Wichser A, Schoenenberger $R$, Wick $P$, et al. Investigating the accumulation and translocation of titanium dioxide nanoparticles with different surface modifications in static and dynamic human placental transfer models. Eur J Pharm Biopharm. 2019;142:488-97.

131. Semmler-Behnke M, Lipka J, Wenk A, et al. Size dependent translocation and fetal accumulation of gold nanoparticles from maternal blood in the rat. Part Fibre Toxicol. 2014;11:33. https://doi.org/10.1186/s12989-014-0033-9.

132. Huang J-P, Hsieh PCH, Chen C-Y, Wang T-Y, Chen P-C, Liu C-C, et al. Nanoparticles can cross mouse placenta and induce trophoblast apoptosis. Placenta. 2015;36:1433-41.

133. Myllynen PK, Loughran MJ, Howard CV, Sormunen R, Walsh AA, Vähäkangas $\mathrm{KH}$, et al. Kinetics of gold nanoparticles in the human placenta. Reprod Toxicol. 2008;26:130-7.

134. Aengenheister L, Dietrich D, Sadeghpour A, Manser P, Diener L, Wichser A, et al. Gold nanoparticle distribution in advanced in vitro and ex vivo human placental barrier models. J Nanobiotechnol. 2018;16:79.

135. Tian X, Zhu M, Du L, Wang J, Fan Z, Liu J, et al. Intrauterine inflammation increases materno-fetal transfer of gold nanoparticles in a size-dependent manner in murine pregnancy. Small. 2013;9:2432-9.

136. Freemark M. Regulation of maternal metabolism by pituitary and placenta hormones: roles in fetal development and metabolic programming. Horm Res. 2006;65:41-9.

137. Napso T, Yong HEJ, Lopez-Tello J, Sferruzzi-Perri AN. The role of placental hormones in mediating maternal adaptations to support pregnancy and lactation. Front Physiol. 2018;9:1-39.

138. lavicoli I, Fontana $L$, Leso V, Bergamaschi $A$. The effects of nanomaterials as endocrine disruptors. Int J Mol Sci. 2013;14:16732-801.

139. Kong L, Tang M, Zhang T, Wang D, Hu K, Lu W, Wei C, Liang G, Pu Y. Nickel nanoparticles exposure and reproductive toxicity in healthy adult rats. Int J Mol Sci. 2014;15(11):21253-69. https://doi.org/10.3390/ijms151121253.
140. Lu X, Zhu Y, Zhu T. Endocrine System. In: Fadeel B, Pietroiusti A, Shvedova AABT-AE of EN (Second E, editors. Advers Eff Eng Nanomater. Academic Press; 2017. p. 339-55. https://www.elsevier.com/books/adverse-effects-ofengineered-nanomaterials/fadeel/978-0-12-809199-9.

141. Kumar P, Magon N. Hormones in pregnancy. Niger Med J. 2012;53:179-83.

142. Shi QJ, Lei ZM, Rao CV, Lin J. Novel role of human chorionic gonadotropin in differentiation of human cytotrophoblasts. Endocrinology. 1993;132:1387-95.

143. Fournier T, Guibourdenche J, Evain-Brion D. Review: hCGs: different sources of production, different glycoforms and functions. Placenta. 2015;36:S60-5

144. Zygmunt M, Herr F, Keller-Schoenwetter S, Kunzi-Rapp K, Münstedt K, Rao $\mathrm{CV}$, et al. Characterization of human chorionic gonadotropin as a novel angiogenic factor. J Clin Endocrinol Metab. 2002;87:5290-6.

145. Toth P, Lukacs H, Gimes G, Sebestyen A, Pasztor N, Paulin F, et al. Clinical importance of vascular hCG / LH receptors-a review. Reprod Biol. 2001;1(2):5-11.

146. Korevaar TIM, Steegers EAP, Pop VJ, Broeren MA, Chaker L, de Rijke YB, et al. Thyroid autoimmunity impairs the thyroidal response to human chorionic gonadotropin: two population-based prospective cohort studies. J Clin Endocrinol Metab. 2016:102:69-77.

147. Berkane N, Liere P, Oudinet J-P, Hertig A, Lefèvre G, Pluchino N, et al. From pregnancy to preeclampsia: a key role for estrogens. Endocr Rev. 2017;38: 123-44.

148. Dante G, Vaccaro V, Facchinetti F. Use of progestagens during early pregnancy. Facts Views Vis ObGyn. 2013;5:66-71.

149. Miranda A, Sousa N. Maternal hormonal milieu influence on fetal brain development. Brain Behav. 2018:8:1-23.

150. Murphy VE, Smith R, Giles WB, Clifton VL. Endocrine regulation of human fetal growth: the role of the mother, placenta, and fetus. Endocr Rev. 2006;27:141-69.

151. Laron Z. Insulin-like growth factor 1 (IGF-1): a growth hormone. Mol Pathol. 2001:54:311-6.

152. Forbes K, Westwood M. The IGF axis and placental function. Horm Res Paediatr. 2008:69:129-37.

153. Fowden AL. The insulin-like growth factors and feto-placental growth. Placenta. 2003:24:803-12

154. Tsoli M, Kaltsas G. Immune system effects on the endocrine system. Endotext. MDText.com, Inc.; 2000.

155. de Haas S, Ghossein-Doha C, van Kuijk SMJ, van Drongelen J, Spaanderman MEA. Physiological adaptation of maternal plasma volume during pregnancy: a systematic review and meta-analysis. Ultrasound Obstet Gynecol. 2017:49:177-87.

156. Osol G, Mandala M. Maternal uterine vascular remodeling during pregnancy. Physiology. 2009;24:58-71.

157. Stapleton PA. Gestational nanomaterial exposures: microvascular implications during pregnancy, fetal development and adulthood. J Physiol. 2016:594:2161-73.

158. Granger JP, Alexander BT, Llinas MT, Bennett WA, Khalil RA. Pathophysiology of preeclampsia: linking placental ischemia/hypoxia with microvascular dysfunction. Microcirculation. 2002;9:147-60.

159. Khong TY. Placental vascular development and neonatal outcome. Semin Neonatol. 2004;9:255-63.

160. Weckman AM, Ngai M, Wright J, McDonald CR, Kain KC. The impact of infection in pregnancy on placental vascular development and adverse birth outcomes. Front. Microbiol. 2019;10:1924.

161. Erickson AC, Arbour L. The shared pathoetiological effects of particulate air pollution and the social environment on fetal-placental development. J Environ Public Health. 2014;2014:901017.

162. Vidanapathirana AK, Thompson LC, Herco M, Odom J, Sumner SJ, Fennell $\mathrm{TR}$, et al. Acute intravenous exposure to silver nanoparticles during pregnancy induces particle size and vehicle dependent changes in vascular tissue contractility in Sprague Dawley rats. Reprod Toxicol. 2018;75:10-22.

163. Vidanapathirana AK, Thompson LC, Odom J, et al. Vascular tissue contractility changes following late gestational exposure to multi-walled carbon nanotubes or their dispersing vehicle in Sprague Dawley rats. J Nanomed Nanotechnol. 2014:5(3):201. https://doi.org/10.4172/2157-7439.1000201.

164. Stapleton PA, Minarchick VC, Yi J, Engels K, McBride CR, Nurkiewicz TR. Maternal engineered nanomaterial exposure and fetal microvascular function: does the Barker hypothesis apply? Am J Obstet Gynecol. 2013;209: 227 e1-227.e11.

165. Stapleton PA, McBride CR, Yi J, Abukabda AB, Nurkiewicz TR. Estrous cycledependent modulation of in vivo microvascular dysfunction after nanomaterial inhalation. Reprod Toxicol. 2018;78:20-8. 
166. Bowdridge EC, Abukabda AB, Engles KJ, McBride CR, Batchelor TP, Goldsmith WT, et al. Maternal engineered nanomaterial inhalation during gestation disrupts vascular kisspeptin reactivity. Toxicol Sci. 2019;169:524-33.

167. Abukabda AB, McBride CR, Batchelor TP, Goldsmith WT, Bowdridge EC, Garner KL, et al. Group II innate lymphoid cells and microvascular dysfunction from pulmonary titanium dioxide nanoparticle exposure. Part Fibre Toxicol. 2018;15:43.

168. Wolfe A, Hussain MA. The emerging role(s) for kisspeptin in metabolism in mammals. Front Endocrinol (Lausanne). 2018;9:184.

169. Learmont JG, Poston L. Nitric oxide is involved in flow-induced dilation of isolated human small fetoplacental arteries. Am J Obstet Gynecol. 1996;174:583-8.

170. Mandler WK, Nurkiewicz TR, Porter DW, Kelley EE, Olfert IM. Microvascular dysfunction following multiwalled carbon nanotube exposure is mediated by thrombospondin-1 receptor CD47. Toxicol Sci. 2018;165:90-9.

171. Hirashima M, Lu Y, Byers L, Rossant J. Trophoblast expression of fms-like tyrosine kinase 1 is not required for the establishment of the maternal-fetal interface in the mouse placenta. Proc Natl Acad Sci U S A. 2003;100:15637-42.

172. Acar N, Ustunel I, Demir R. Uterine natural killer (UNK) cells and their missions during pregnancy: a review. Acta Histochem. 2011;113:82-91.

173. Anne Croy B, Van Den Heuvel MJ, Borzychowski AM, Tayade C. Uterine natural killer cells: a specialized differentiation regulated by ovarian hormones. Immunol Rev. 2006;214:161-85.

174. Gong H, Chen Y, Xu J, Xie X, Yu D, Yang B, et al. The regulation of ovary and conceptus on the uterine natural killer cells during early pregnancy. Reprod Biol Endocrinol. 2017;15:73.

175. Jacobo-Estrada T, Santoyo-Sánchez M, Thévenod F, Barbier O. Cadmium handling, toxicity and molecular targets involved during pregnancy: Lessons from experimental models. Int J Mol Sci. 2017;18:1590.

176. Hu J, Wang H, Hu Y-F, Xu X-F, Chen Y-H, Xia M-Z, et al. Cadmium induces inflammatory cytokines through activating Akt signaling in mouse placenta and human trophoblast cells. Placenta. 2018;65:7-14.

177. Nakashima A, Higashisaka K, Kusabiraki T, Aoki A, Ushijima A, Ono Y, et al. Autophagy is a new protective mechanism against the cytotoxicity of platinum nanoparticles in human trophoblasts. Sci Rep. 2019;9:5478.

178. Van Niel G, D'Angelo G, Raposo G. Shedding light on the cell biology of extracellular vesicles. Nat. Rev. Mol. Cell Biol. 2018;19:213-28.

179. Gómez-Molina C, Sandoval M, Henzi R, Ramírez JP, Varas-Godoy M, Luarte A, et al. Small extracellular vesicles in rat serum contain astrocyte-derived protein biomarkers of repetitive stress. Int J Neuropsychopharmacol. 2019; 22:232-46.

180. Yang T, Martin P, Fogarty B, Brown A, Schurman K, Phipps R, et al. Exosome delivered anticancer drugs across the blood-brain barrier for brain cancer therapy in Danio rerio. Pharm Res. 2015;32:2003-14.

181. Zhuang X, Xiang X, Grizzle W, Sun D, Zhang S, Axtell RC, et al. Treatment of brain inflammatory diseases by delivering exosome encapsulated anti-inflammatory drugs from the nasal region to the brain. Mol Ther. 2011;19:1769-79.

182. Raposo G, Nijman HW, Stoorvogel W, Liejendekker R, Harding CV, Melief CJ, et al. B lymphocytes secrete antigen-presenting vesicles. J Exp Med. 1996; 183:1161-72.

183. Zitvogel L, Regnault A, Lozier A, Wolfers J, Flament C, Tenza D, et al. Eradication of established murine tumors using a novel cell-free vaccine: dendritic cell derived exosomes. Nat Med. 1998:4:594-600.

184. Antonyak MA, Li B, Boroughs LK, Johnson JL, Druso JE, Bryant KL, et al. Cancer cell-derived microvesicles induce transformation by transferring tissue transglutaminase and fibronectin to recipient cells. Proc Natl Acad Sci U S A. 2011;108:4852-7.

185. Salomon C, Torres MJ, Kobayashi M, Scholz-Romero K, Sobrevia L, Dobierzewska A, et al. A gestational profile of placental exosomes in maternal plasma and their effects on endothelial cell migration. PLoS One. 2014;9:e98667

186. Sabapatha A, Gercel-taylor C, Taylor DD. Specific isolation of placentaderived exosomes from the circulation of pregnant women and their immunoregulatory consequences. Am J Reprod Immunol. 2006;56:345-55.

187. Pillay P, Maharaj N, Moodley J, Mackraj I. Placental exosomes and preeclampsia: Maternal circulating levels in normal pregnancies and, early and late onset pre-eclamptic pregnancies. Placenta. 2016;46:18-25.

188. Vargas A, Zhou S, Éthier-Chiasson M, Flipo D, Lafond J, Gilbert C, et al. Syncytin proteins incorporated in placenta exosomes are important for cell uptake and show variation in abundance in serum exosomes from patients with preeclampsia. FASEB J. 2014:28:3703-19.
189. Baig S, Lim JY, Fernandis AZ, Wenk MR, Kale A, Su LL, et al. Lipidomic analysis of human placental Syncytiotrophoblast microvesicles in adverse pregnancy outcomes. Placenta. 2013;34:436-42.

190. Baig S, Kothandaraman N, Manikandan J, Rong L, EEK, Hill J, et al. Proteomic analysis of human placental syncytiotrophoblast microvesicles in preeclampsia. Clin Proteomics. 2014;11:40.

191. Ospina-Prieto S, Chaiwangyen W, Herrmann J, Groten T, Schleussner E, Markert UR, et al. MicroRNA-141 is upregulated in preeclamptic placentae and regulates trophoblast invasion and intercellular communication. Transl Res. 2016;172:61-72.

192. Salomon C, Scholz-Romero K, Sarker S, Sweeney E, Kobayashi M, Correa P, et al. Gestational diabetes mellitus is associated with changes in the concentration and bioactivity of placenta-derived exosomes in maternal circulation across gestation. Diabetes. 2016;65:598-609.

193. Zhu M, Tian X, Song X, Li Y, Tian Y, Zhao Y, et al. Nanoparticle-induced exosomes target antigen-presenting cells to initiate Th1-type immune activation. Small. 2012;8:2841-8.

194. Zhu M, Li Y, Shi J, Feng W, Nie G, Zhao Y. Exosomes as extrapulmonary signaling conveyors for nanoparticle-induced systemic immune activation. Small. 2012:8:404-12.

195. Andersson-Willman B, Gehrmann U, Cansu Z, Buerki-Thurnherr T, Krug HF, Gabrielsson S, et al. Effects of subtoxic concentrations of $\mathrm{TiO} 2$ and $\mathrm{ZnO}$ nanoparticles on human lymphocytes, dendritic cells and exosome production. Toxicol Appl Pharmacol. 2012;264:94-103.

196. Logozzi M, Mizzoni D, Bocca B, Di Raimo R, Petrucci F, Caimi S, et al. Human primary macrophages scavenge AuNPs and eliminate it through exosomes. A natural shuttling for nanomaterials. Eur J Pharm Biopharm. 2019;137:23-36.

197. Sancho-Albero M, Navascués N, Mendoza G, Sebastián V, Arruebo M, MartínDuque $P$, et al. Exosome origin determines cell targeting and the transfer of therapeutic nanoparticles towards target cells. J Nanobiotechnology. 2019:17:16.

198. Landvik NE, Skaug V, Mohr B, Verbeek J, Zienolddiny S. Criteria for grouping of manufactured nanomaterials to facilitate hazard and risk assessment, a systematic review of expert opinions. Regul Toxicol Pharmacol. 2018;95:270-9.

199. Karczewski J, Śledzińska E, Baturo A, Jończyk I, Maleszko A, Maleszko A, et al. Obesity and inflammation. Eur Cytokine Netw. 2018;29:83-94.

200. Nymark P, Bakker M, Dekkers S, Franken R, Fransman W, García-Bilbao A, et al. Toward rigorous materials production: New approach methodologies have extensive potential to improve current safety assessment practices. Small. 2020;16:1904749.

201. Campagnolo L, Lacconi V, Massimiani M, Magrini A, Pietroiusti A, Manley G. In vitro experimental models to study the efficiency of the placental barrier for environmental toxicants : Tumor cell lines versus trophoblast primary cells. Biomed Prev. 2018:1:210-2.

202. Boos JA, Misun PM, Michlmayr A, Hierlemann A, Frey O. Microfluidic multitissue platform for advanced embryotoxicity testing in vitro. Adv Sci. 2019;6:1900294

203. Nguyen $\mathrm{VH}$, Lee BJ. Protein corona: A new approach for nanomedicine design. Int. J Nanomedicine. 2017;12:3137-51.

204. Shannahan J. The biocorona: a challenge for the biomedical application of nanoparticles. Nanotechnol Rev. 2017;6:345-53.

\section{Publisher's Note}

Springer Nature remains neutral with regard to jurisdictional claims in published maps and institutional affiliations.

Ready to submit your research? Choose BMC and benefit from:

- fast, convenient online submission

- thorough peer review by experienced researchers in your field

- rapid publication on acceptance

- support for research data, including large and complex data types

- gold Open Access which fosters wider collaboration and increased citations

- maximum visibility for your research: over $100 \mathrm{M}$ website views per year

At $\mathrm{BMC}$, research is always in progress.

Learn more biomedcentral.com/submissions 